Arruda, A. M., Pereira, C., Sousa, E. de, Pimenta, J., Detry, C. y Gomes, J. (2018): “Chões de Alpompé (Vale de Figueira, Santarém): lendas e narrativas", Spal 27.2: 201-227. DOI: http://dx.doi.org/10.12795/spal.2018i27.20

\title{
CHÕES DE ALPOMPÉ (VALE DE FIGUEIRA, SANTARÉM): LENDAS E NARRATIVAS
}

\section{CHÕES DE ALPOMPÉ (VALE DE FIGUEIRA, SANTARÉM): TALES AND NARRATIVE}

\author{
ANA MARGARIDA ARRUDA \\ Uniarq, Universidade de Lisboa. \\ Correo-e: a.m.arruda@letras.ulisboa.pt ORCID: https://orcid.org/0000-0002-7446-1104 \\ CARLOS PEREIRA \\ FCT, Uniarq, Universidade de Lisboa, Museo de Cáceres. \\ Correo-e: carlos_samuel_pereira@hotmail.com ORCID: https://orcid.org/0000-0002-4116-3602 \\ ELISA DE SOUSA \\ Uniarq, Universidade de Lisboa. \\ Correo-e: e.sousa@campus.ul.pt ORCID: https://orcid.org/0000-0003-3160-108X \\ JOÃO PIMENTA \\ CEAX (Centro de Estudos Arqueológicos Vila Franca de Xira). \\ Correo-e: joao.marques@cm-vfxira.pt ORCID: https://orcid.org/0000-0001-5149-5566 \\ CLEIA DETRY \\ Uniarq, Universidade de Lisboa. \\ Correo-e: cdetry@gmail.com ORCID: https://orcid.org/0000-0002-5359-2500 \\ JOÃO GOMES \\ Arqueólogo Independente \\ Correo-e: joaopbgomes.93@gmail.com ORCID: https://orcid.org/0000-0002-8532-9870
}

Resumo: Os trabalhos de campo realizados em 2015 e 2016 nos Chões de Alpompé permitiram recolher abundante informação sobre as suas ocupações antigas. A existência de uma Idade do Ferro, que nos momentos iniciais é de matriz orientalizante e que está materializada em materiais e também em estruturas domésticas, tornou possível voltar ao debate acerca da localização de Móron, a "cidade" indígena sobre a qual Décimo Júnio Bruto instalou um acampamento em 138 a.n.e., agora com dados devidamente contextualizados. A tipologia do acampamento do Galaico pode também ser discutida tendo em consideração os dados agora obtidos, nomeadamente os que se referem à muralha de terra batida que envolve, em parte, o planalto e à estrutura negativa, de tipo "fosso", paralela àquela detectada durante os trabalhos de campo. A sequência ocupacional do sítio e o papel que este representou durante as guerras sertorianas foram devidamente valorizados.
Abstract: Archaeological excavations and surveys carried out in 2015 and 2016 in Chões de Alpompé allowed us to gather significant data concerning its ancient occupations. The existence of an Iron Age, which initially is characterized by an orientalizing matrix, reflected both in the artifacts and also in domestic structures, made it possible to return to the debate that entails the location of Móron, the native "city" on which Décimo Júnio Bruto build a camp in 138 BCE, now with properly contextualized data. The typology of the Galaico camp can also be discussed taking into account the data now obtained, namely those that refer to the defensive wall that partly surrounds the plateau and the negative structure, of a "moat" type, parallel to that one, that was detected during the field work. The occupational sequence of the settlement and the role it played during the Sertorian wars were duly valued. Evidence of a presence in Islamic times provided 
As evidências de uma presença em época islâmica forneceram contornos mais precisos às informações textuais sobre a sua utilização como acampamento militar em meados do século XII.

Palavras-chave: Estuário do Tejo; acampamentos militares; Décimo Júnio Bruto; guerras sertorianas; romanização.

\section{INTRODUÇÃO}

O sítio arqueológico de Chões de Alpompé está implantado num vasto e recortado planalto sobranceiro ao rio Alviela, junto à sua confluência com o Tejo. Tem cerca de 20 ha. e 96 metros de altura (figs. 1, 2 e 3).

Localiza-se na freguesia de S. Vicente do Paúl, concelho de Santarém, e tem as seguintes coordenadas geográficas: Latitude: 39¹9’34.11’N; Longitude: 8०35'54.72’W (-8.597917; 39.329397).

Foi reconhecido nos anos 50 do século passado, quando Amorim Girão e Bairrão Oleiro o identificaram (1953), tendo, a partir de aí, sido sistematicamente referido e citado como um dos mais importantes sítios arqueológicos portugueses, concretamente no que se refere ao processo da conquista romana do território more precise contours to textual information about its use as a military encampment in the mid-twelfth century.

Keywords: Tagus estuary; militar encampments; Décimo Júnio Bruto; Sertorian wars; romanization.

ocidental da Península Ibérica. Há pouco tempo, dois de nós (J.P. e A.M.A.) tiveram oportunidade de registar a já longa história dos trabalhos e das leituras sobre o sítio (Pimenta e Arruda 2014), pelo que dispensamos voltar à sua biografia.

Parece importante, contudo, referir que a grande extensão, a quantidade e a qualidade do espólio recuperado e a visibilidade de um sistema defensivo em talude, particularmente bem conservado, foram certamente responsáveis pela notoriedade que Chões de Alpompé alcançou no panorama arqueológico português, sobretudo para a época romano-republicana. Porém, até 2015 nunca aí haviam sido realizadas escavações arqueológicas, sendo os dados existentes, que suportavam as diversas interpretações ensaiadas, oriundos de prospecções, algumas autorizadas, mas a maioria

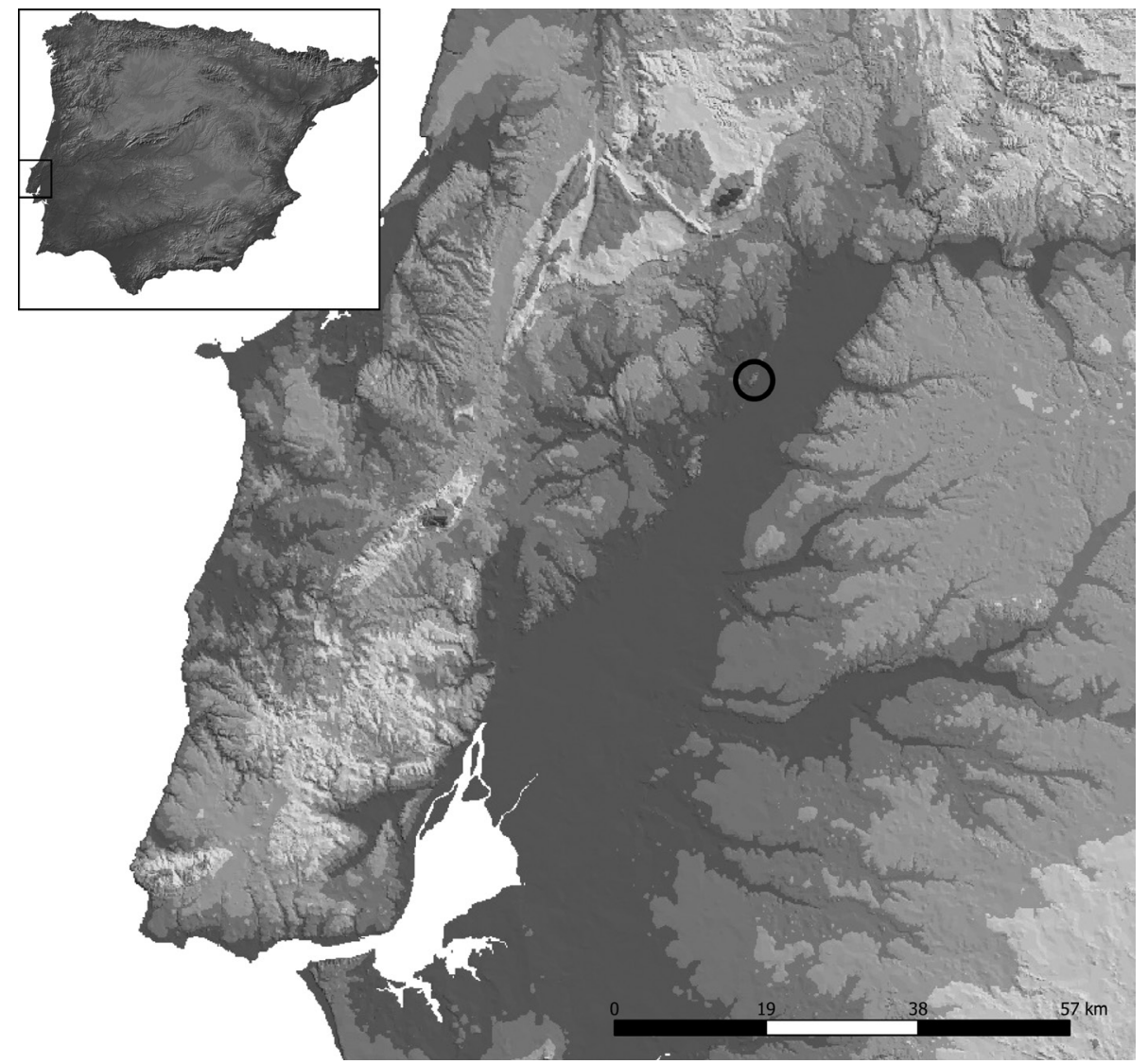

Figura 1. Localização de Chões de Alpompé em MDT com espaçamento de $50 \mathrm{~m}$ produzido a partir de SCN à escala 1:50 000 . 


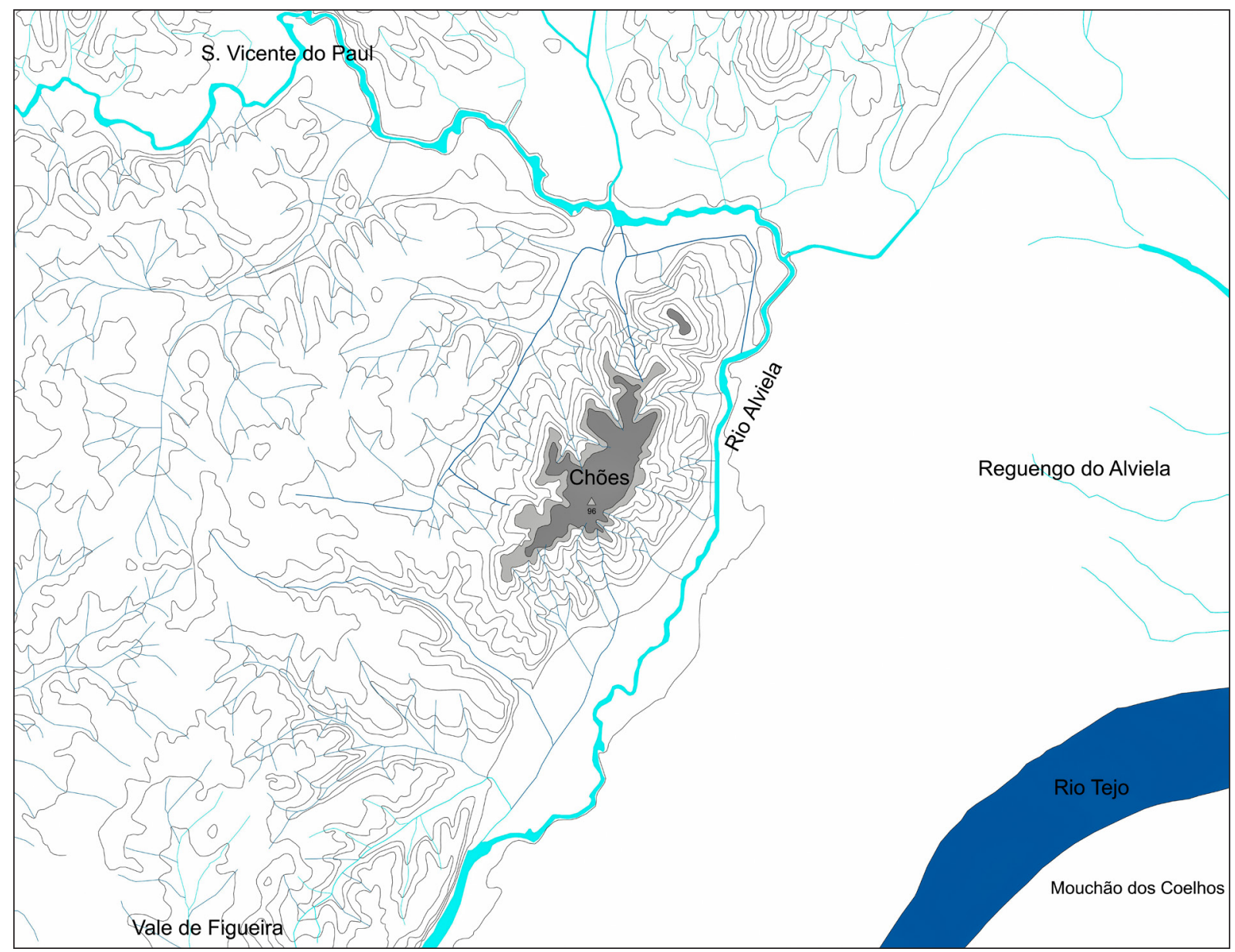

Figura 2. Planta de Chões de Alpompé, com as curvas de nível e localização das linhas de água, produzida a partir da carta militar 1: 25 000, folha . $^{\circ} 341$, de 1969.

Figura 3. Chões de Alpompé visto desde Reguengo de Alviela, vertente Este.

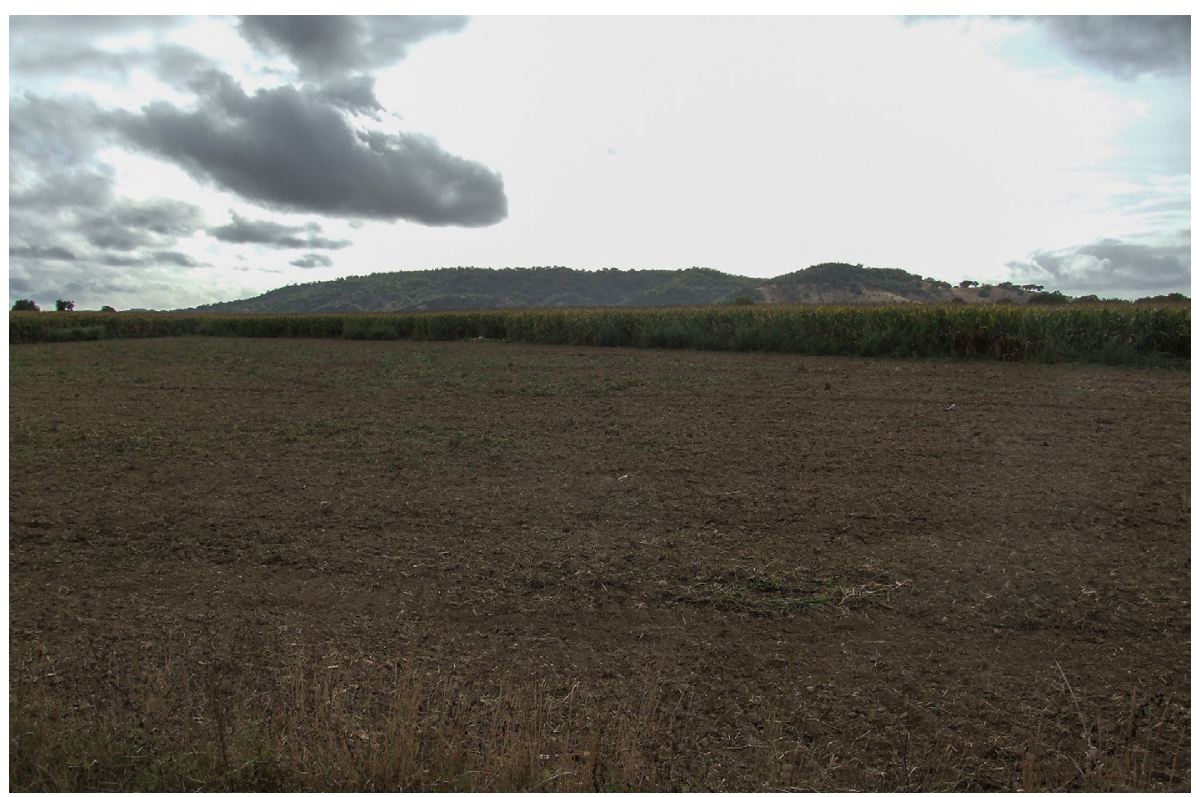

ISSN: 1133-4525 ISSN-e: 2255-3924 
clandestina, e de verdadeiros "saques". Certo é, contudo, que todos proporcionaram impressionantes resultados ao nível dos espólios recolhidos, hoje divididos por várias instituições e por inúmeras e dispersas colecções privadas, impossíveis de contabilizar.

Deve registrar-se também que o debate em torno de Chões de Alpompé se prendeu, quase sempre, com questões que dizem respeito à chamada Geografia Histórica, uma vez que, desde cedo, se pretendeu fazer corresponder o sítio à "cidade" que o cônsul Décimo Júnio Bruto terá usado para estacionar o seu exército, Móron, antes da campanha ao Noroeste, ainda que alguns autores tenham suportado hipóteses distintas para a localização do núcleo urbano mencionado por Estrabão (III.3.1.) (Alarcão 1983: 36; 2002: 37-38; Mantas 1986: 590-592; Kalb e Hock 1988).

A identificação dos Chões de Alpompé com Morón teve, sobretudo, por base o espólio que foi recolhido nos distintos trabalhos no terreno, todos, como já dissemos, de prospecção.

Entre os primeiros, deve destacar-se o elevado número de ânforas vinárias oriundas da Península Itálica, quase todas com características morfológicas que permitem avançar uma cronologia de meados do terceiro quartel do século II a.n.e., integrando os tipos Greco-itálico e Dressel 1 arcaica (Diogo 1982; Fabião 1989; Ferreira, Catarino e Pinho 1993; Diogo e Trindade 19931994; Bargão 2006; Pimenta e Arruda 2104). Como sabemos, a coexistência de ambos os tipos é frequente em contextos do mesmo quartel, de que aqui se destacam, por razões óbvias, os casos de Lisboa (Pimenta 2005) e de Valência (Ribera Lacomba 1998; 2002). Também as T-9.1.1.1. de Ramon Torres (1995: 226-227), com origem na Baía de Cádis (Diogo 1982; 1993; Diogo e Trindade 1993-94) e as Tripolitanas Antigas, norte-africanas (Fabião 1989; Diogo 1993; Ferreira, Catarino e Pinho 1993; Diogo e Trindade 1993-94; Bargão 2006), são compatíveis com a mesma cronologia, estando, aliás, associadas nos contextos acima referidos. Mais difícil de datar são as Mañá C2b (T-7.4.3.2 ou T-7.4.3.3) (Diogo 1982; Fabião 1989; Diogo e Trindade 1993-94), uma vez que foram utilizadas até momentos bastante tardios.

As excepções são as ânforas itálicas Lamboglia 2 (Fabião 1989, Diogo e Trindade 1993-94) e Dressel 2/4 (Diogo e Trindade 1993-94), mais tardias e raras, sobretudo a última, e a da Classe 67/Ovóide 1 (Diogo e Trindade 1993-94), oriunda do vale do Guadalquivir.

O conjunto numismático conhecido é muito numeroso, concretamente 150 moedas (Ruivo 1999), constituindo-se como «...o maior conjunto de moeda romana de época republicana, resultante de perdas individuais conhecido no ocidente da Península Ibérica...» (Fabião 2014: 13), sendo constituído por exemplares que revelam:

Um momento de introdução / difusão / uso de moeda romana no ocidente em cronologia compatível com a notícia de Estrabão [...], mas também a existência de um regular abastecimento e circulação nas décadas seguintes $[\ldots]$, bem como uma aparente quebra da sua chegada em cronologia compatível com o conflito sertoriano, ainda que a presença dos exemplares mais recentes sugira que não terá de todo cessado a frequência do local (ibidem 14).

A favor de uma instalação militar no local a partir do terceiro quartel do século II a.n.e. falam ainda outros artefactos metálicos, concretamente os que entram na categoria de militaria, como é o caso das glandes de chumbo, muito abundantes no sítio (112 exemplares), sendo de sublinhar a demonstrada existência de uma officina de fabrico de glandes plumbeae no local (Fabião, Pereira e Pimenta 2015: 114-129).

A grande maioria destes materiais é, pois, absolutamente compatível com uma instalação militar, e, do ponto de vista cronológico, também o é com a presença, no vale do Tejo, do general romano conhecido por "o Galaico". Ainda assim, o local terá tido aparentemente papel activo durante os conflitos sertorianos, pelo menos a avaliar pelo conjunto numismático conhecido (Ruivo 1999).

Por outro lado, em certos troços do planalto dos Chões é visível, junto às vertentes, um talude bem conservado, construído com terra, que seguramente correspondeu a uma estrutura defensiva, o que acentua o carácter militar do sítio.

Outros espólios, também recolhidos à superfície ainda no século XX, sobretudo cerâmicos, mas também metálicos, remetiam, porém, para uma cronologia anterior, da Idade do Ferro. De facto, alguns materiais publicados ainda no século passado deixavam antever uma ocupação sidérica com alguma expressão, é o caso da cerâmica ática e de algumas ânforas (Zbyszweski et al. 1968; Diogo 1993). Estes dados asseguravam a existência de um povoado indígena, pré-romano, que parecia, contudo, não recuar para trás do século IV a.n.e.

Assim, a localização geográfica, a implantação topográfica, os materiais de superfície e a muralha de terra batida conjugam-se no sentido de fornecer sentido às propostas mais frequentemente defendidas para o sítio: Chões de Alpompé correspondia ao povoado indígena designado por Morón que tinha sido utilizado por Décimo Júnio Bruto, em 138 a.n.e. 
Outro tipo de informação sobre o sítio, neste caso exclusivamente textual, dizia respeito a uma provável ocupação durante a época islâmica (Pimenta, Henriques e Mendes 2012). De facto, na Crónica de Afonso Henriques de Duarte Nunes de Leão refere-se:

E todos vierão per Alentejo. E passando o rio, dia de Sam Ioam Baptista daquele anno de M.CLXXXIIII. Nesse mesmo dia forão sobre o castello de Torres Novas, e o destruirão. A segunda feira vierão poer ser arraial em hum monte, que chamão de Pompeio (Leão 1975: 92).

A descrição geográfica é compatível com uma localização deste "monte" em Chões de Alpompé, parecendo também possível retomar a hipótese já formulada por Dias Diogo (1982: 149) de o topónimo actual poder ser relacionado com um acampamento de Pompeu Magno, ou de seu filho, Sexto Pompeu.

Resta ainda referir nesta introdução que nos anos 80 do século XX o sítio foi fortemente atingido pelo plantio de um eucaliptal em quase toda a sua extensão. Antes ainda, uma exploração de saibro junto à vertente Sul provocou também uma destruição considerável numa área relativamente vasta.

\section{OS TRABALHOS DO SÉCULO XXI}

\subsection{O contexto das intervenções no terreno}

No quadro do Projecto "Fenícios no Estuário do Tejo" (PTDC/EPH-ARQ/4901/2012) foram realizadas, em 2014, prospecções no local, conduzidas por João Pimenta e Henrique Mendes, de modo a confirmar uma presença sidérica antiga, presumida por algumas ânforas publicadas por Dias Diogo (1993) e também por outras cerâmicas recuperadas por dois de nós (J. P. e H. M.) em algumas visitas ao sítio.

Nestes trabalhos, a presença de materiais da I Idade do Ferro ficou comprovada, o que determinou a decisão de proceder a sondagens arqueológicas que permitissem uma leitura fundamentada da evolução diacrónica da ocupação dos Chões de Alpompé, no que à Idade do Ferro dizia respeito.

As escavações tiveram lugar no Verão de 2015, tendo sido escavadas quatro áreas de dimensões variadas, todas localizadas em zonas distintas, ainda que, na sua globalidade, na área SE do Planalto (fig. 4). Os trabalhos de campo tiveram a direcção científica de Ana Margarida
Figura 4. Implantação das sondagens realizadas, carta militar 1:25000, folha $\mathrm{n}^{\circ} 341$.

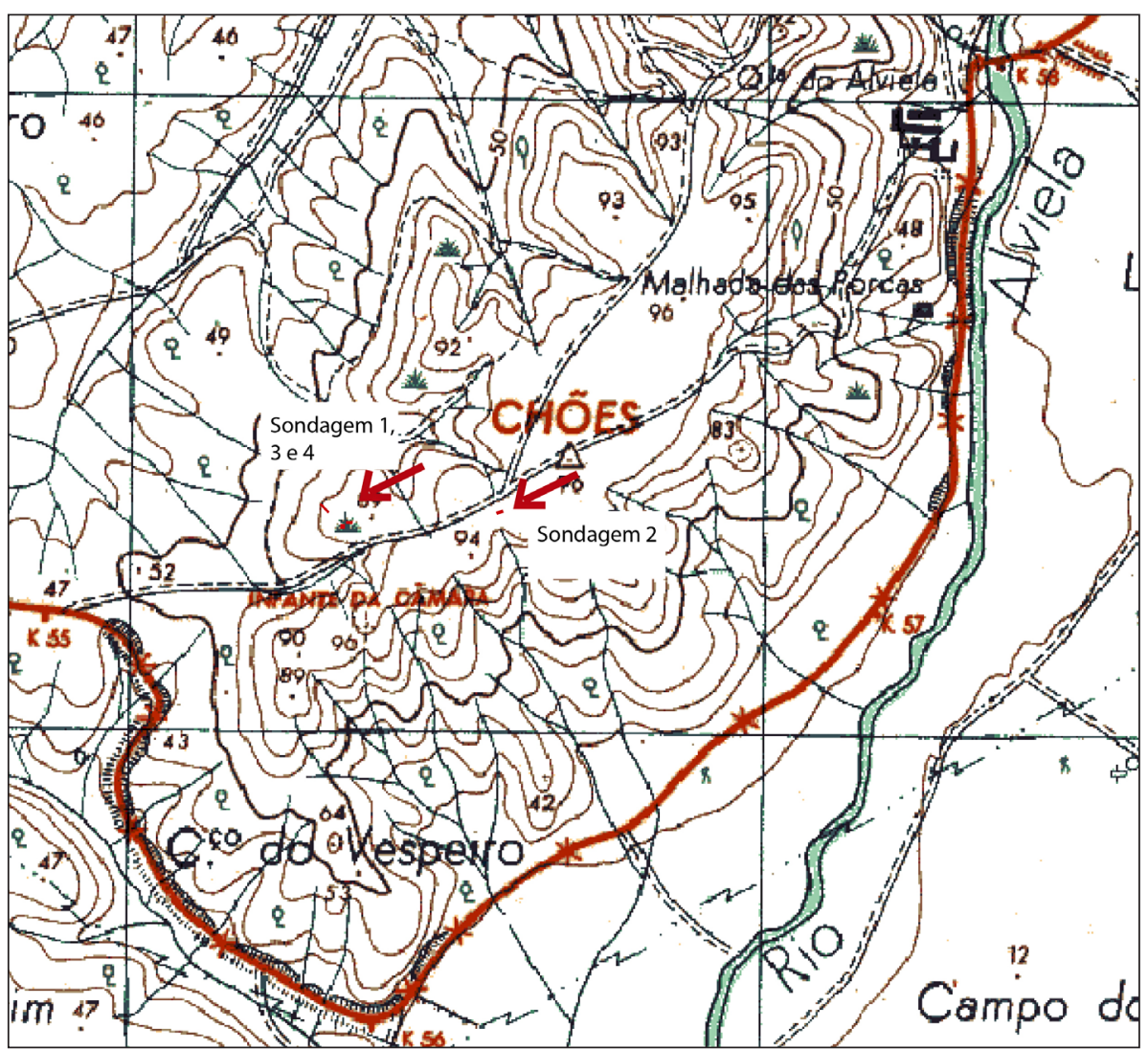




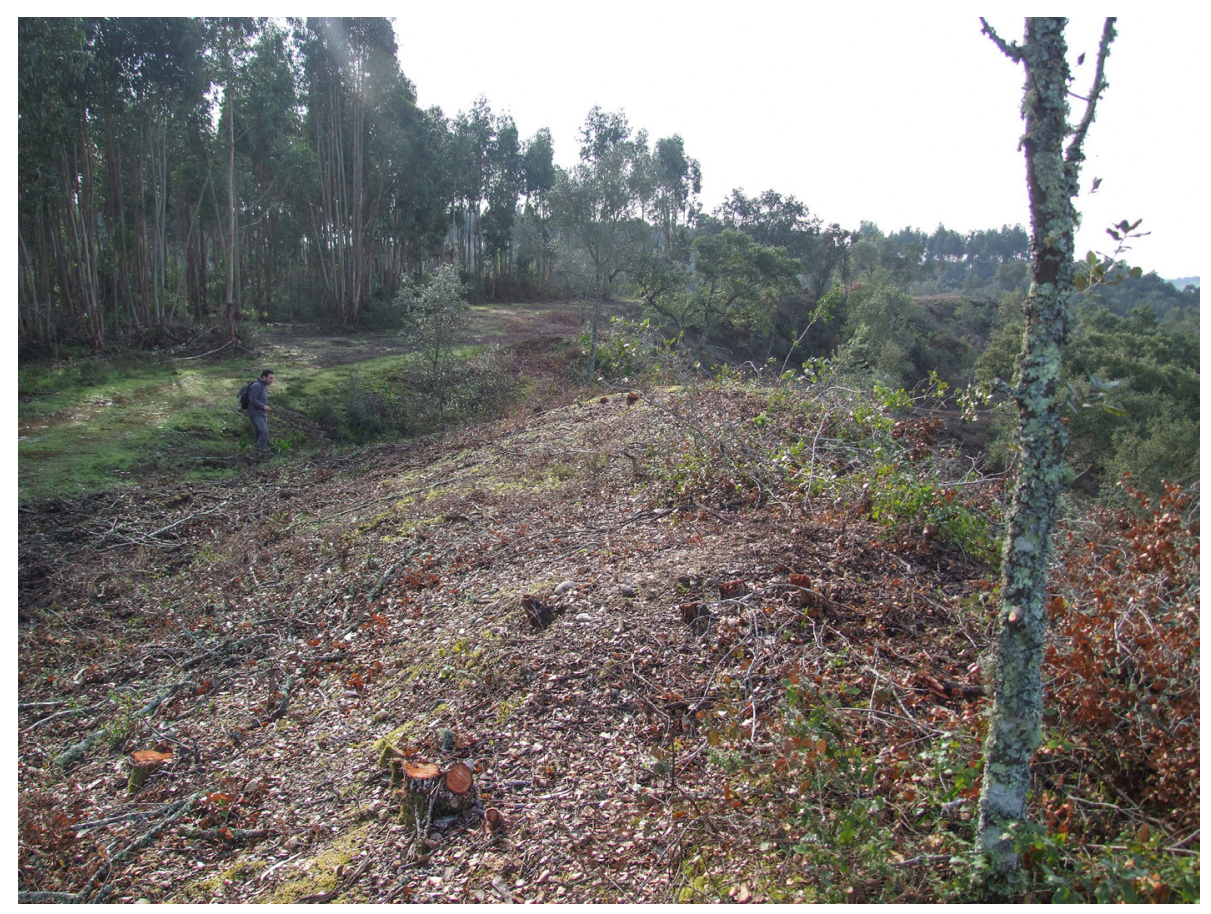

Figura 5. Topo do talude da muralha de terra colocada a descoberto durante os trabalhos de desmatação, pano Oeste (fotografia de Carlos Pereira).

Arruda, tendo sido coordenados por Carlos Pereira, Elisa de Sousa e Rui Soares (Arruda et al. 2015).

Estes trabalhos tinham igualmente como objectivo verificar o estado de conservação do sítio e dos níveis arqueológicos correspondentes às ocupações humanas ao longo da diacronia, face às afectações provocadas pelas acções do século XX, concretamente a exploração do saibro e o plantio do eucaliptal.

No Outono de 2015 e durante o ano de 2016, tiveram lugar trabalhos de acompanhamento da desmatagem das vertentes do planalto dos Chões de Alpompé, promovida pelo proprietário do terreno (fig. 5), que foram coordenados por Carlos Pereira e Ricardo Silva.

\subsection{A(s) sequência(s) estratigráficas}

A escavação arqueológica nos Chões de Alpompé revelou, em dois dos sectores escavados (Sondagem 2 e 3), sequências estratigráficas claras e bem definidas, que se tornam importantes na avaliação da diacronia da ocupação humana do sítio.

Infelizmente, os níveis correspondentes ao período romano foram os mais afectados pela plantação do eucaliptal. Apesar disso foi possível escavar estratos conservados de época romana, concretamente na Sondagem 2, onde inclusivamente foram identificadas estruturas correspondentes à drenagem de águas (fig. 6).
Contudo, uma eventual e provável sequência de ocupação republicana não foi possível de aferir. De facto, se os materiais recuperados à superfície permitem admitir que o planalto dos Chões de Alpompé foi utilizado como acampamento na segunda metade do século II e no contexto das guerras sertorianas, a verdade é que essa situação não pôde ser verificada através da escavação e ainda menos se entre os dois momentos houve um abandono do local, ou se, pelo contrário, algumas tropas aí permaneceram instaladas.

No que à Idade do Ferro diz respeito, houve, porém, oportunidade de observar um conjunto de estratos que se sobrepunham, o que possibilitou a obtenção de dados importantes acerca do desenvolvimento da ocupação sidérica. Na Sondagem 3, foi detectada uma interessante sucessão de estruturas negativas, as mais antigas, e de combustão, as mais recentes, numa sequência de níveis ocupacionais que evidenciaram um uso prolongado da área em época pré-romana. Os estratos, diferenciados do ponto de vista sedimentar, integravam também materiais arqueológicos que permitiram datar a referida sequência. Às duas fossas (figs. 7 e 8) entulhadas com espólios da $1^{\text {a }}$ Idade do Ferro (séculos VII/VI a.n.e.) (figs. 13 e 14), sobrepunham-se pisos de ocupação de terra batida, sobre os quais se construíram pequenas lareiras de forma, grosso modo, circular (fig. 9). Nos sedimentos correspondentes à utilização dessas estruturas de combustão e dos dois pisos onde 


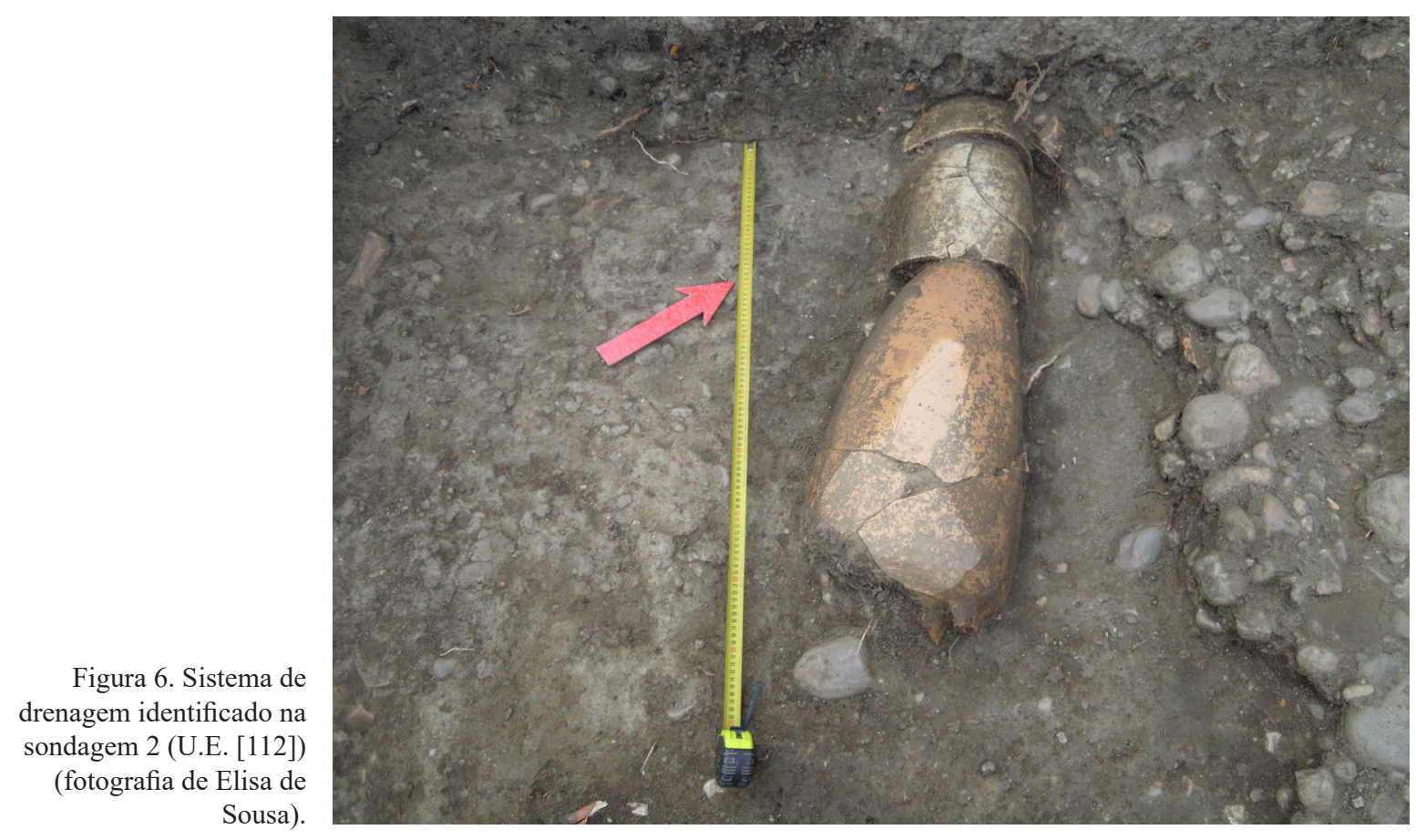

assentavam, também sobrepostos, foram recolhidas cerâmicas que puderam datar-se da $2^{\mathrm{a}}$ Idade do Ferro (séculos IV/III a.n.e.) (figs. 15 e 16).

\subsection{Estruturas domésticas e defensivas}

Os resultados obtidos durante os trabalhos de campo dizem, sobretudo, respeito à Idade do Ferro e à época romano-republicana. Porém, uma fossa, de perfil oval, escavada no substrato geológico, detectada na Sondagem 1, e que deve corresponder a um silo, encontrava-se entulhada com lixos domésticos que evidenciaram uma ocupação de época Islâmica (fig. 10). Entre estes, destacam-se vasos cerâmicos que se incorporam nas categorias mais conhecidas, apresentando os seus melhores paralelos na Alcáçova de Santarém (Viegas e Arruda 1999). Assim, uma instalação em época Islâmica, que as fontes medievais permitiam admitir, ficou demonstrada.

Para a época romana, e no que se refere a estruturas, os resultados não impressionam no que às de âmbito doméstico diz respeito. Contudo, destaca-se a descoberta de um sistema de drenagem particularmente bem conservado (fig. 6). Compunha-se por duas ânforas, estando certamente relacionado com uma área edificada localizada fora do espaço intervencionado.

Muito mais significativos são os dados obtidos sobre o sistema defensivo, quer os de escavação, quer os que resultaram dos trabalhos de acompanhamento da desmatação.

Nos primeiros, cabe a Sondagem que foi marcada no lado exterior da muralha, numa plataforma localizada na base da referida estrutura defensiva, a SO (fig. 4). A sua escavação foi determinada pela necessidade de esclarecer a existência, ou não, de um fosso associado à muralha de terra que é visível em vários troços dos taludes que delimitam o planalto do Chões de Alpompé, como foi defendido desde a identificação do sítio (Girão e Oleiro 1953: 77).

Tornou-se claro que a base do talude da muralha, correspondendo ao substrato geológico, foi afeiçoada e rebaixada. Sobre este havia terras, aparentemente, revolvidas, e vestígios do solo virgem, seguramente proveniente da terraplanagem efectuada, no exterior do acampamento, em época romana. A escavação revelou ainda que o rebaixamento produziu uma estrutura negativa, em cujos enchimentos se recolheram fragmentos de ânforas itálicas, que podem integrar-se nas formas Dressel 1 ou Greco-itálica. Embora o perfil desta estrutura negativa (fig. 11) não se ajuste aos típicos fossos de acampamentos romano-republicanos, o certo é que a existência de uma depressão escavada na área externa e anexa à muralha, que lhe é paralela, é inquestionável.

A existência desse fosso, que muitos autores descartaram tendo em consideração a sua inutilidade face à topografia do terreno e à potente muralha de terra, 


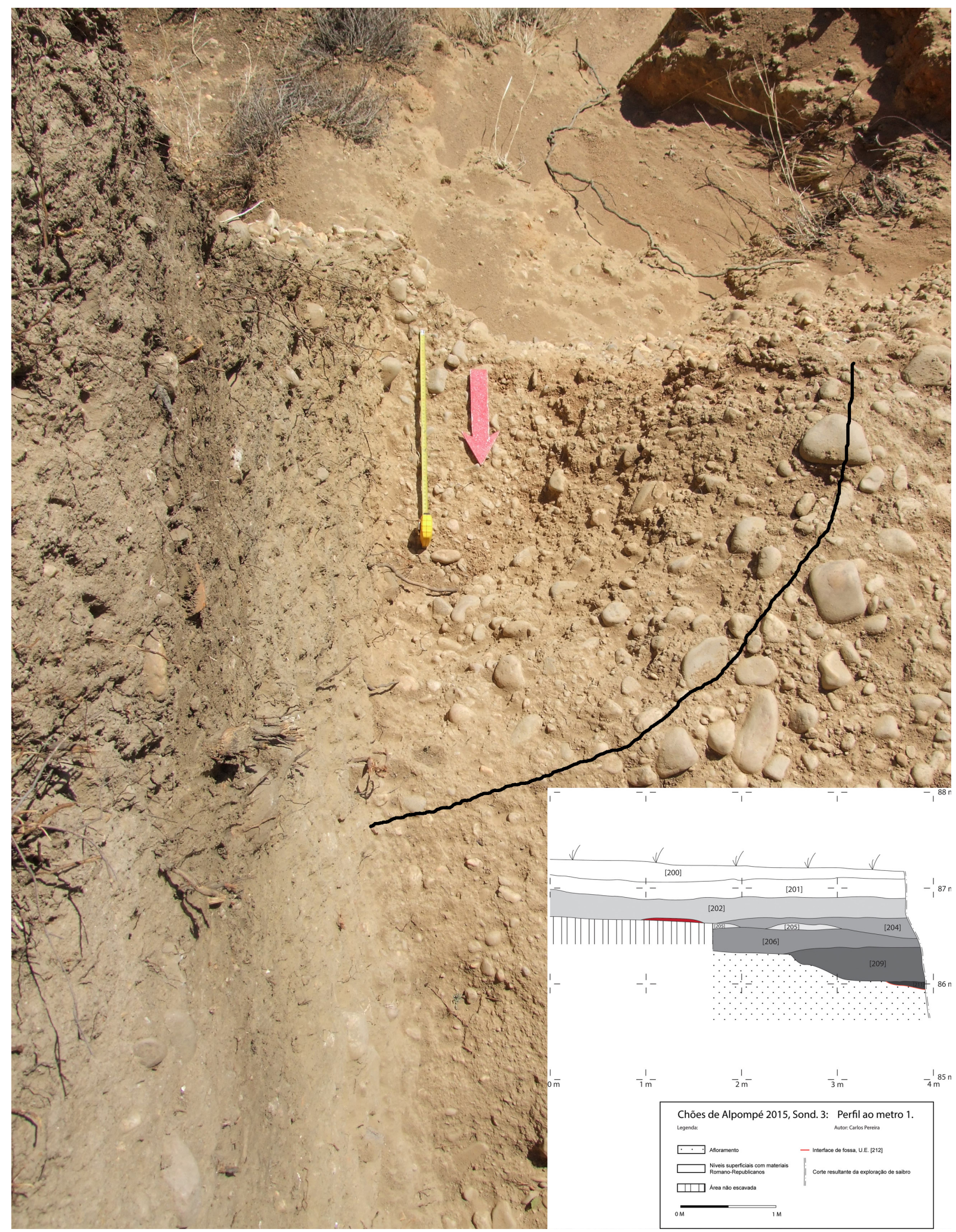

Figura 7. Fossa negativa [212] que cortava o solo virgem (fotografia de Carlos Pereira). No canto inferior direito, perfil da realidade estratigráfica ao metro 1 . 


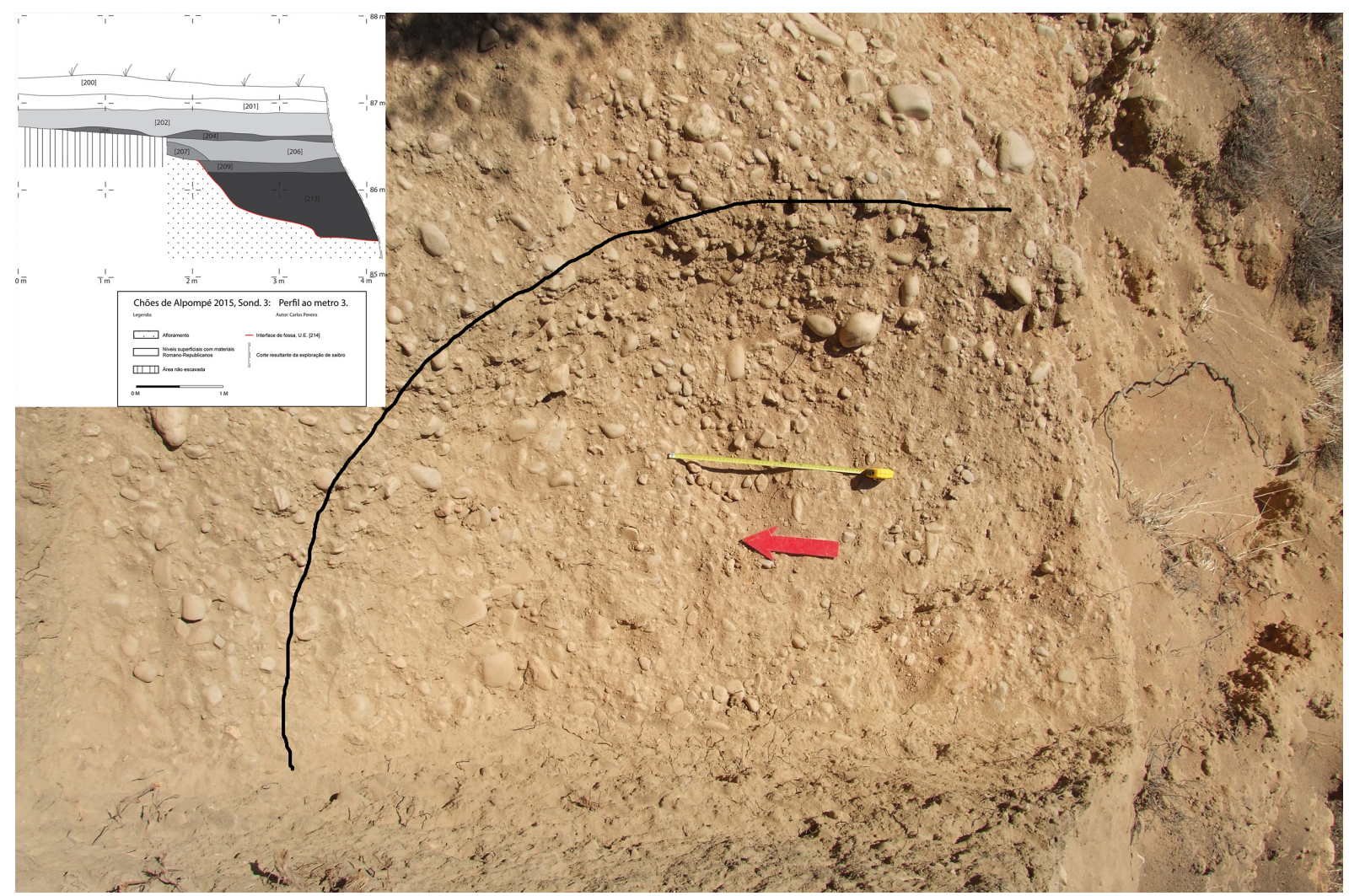

Figura 8. Estrutura negativa [214] que cortava o solo virgem (fotografia de Carlos Pereira). No canto superior esquerdo, perfil da realidade estratigráfica ao metro 3 .

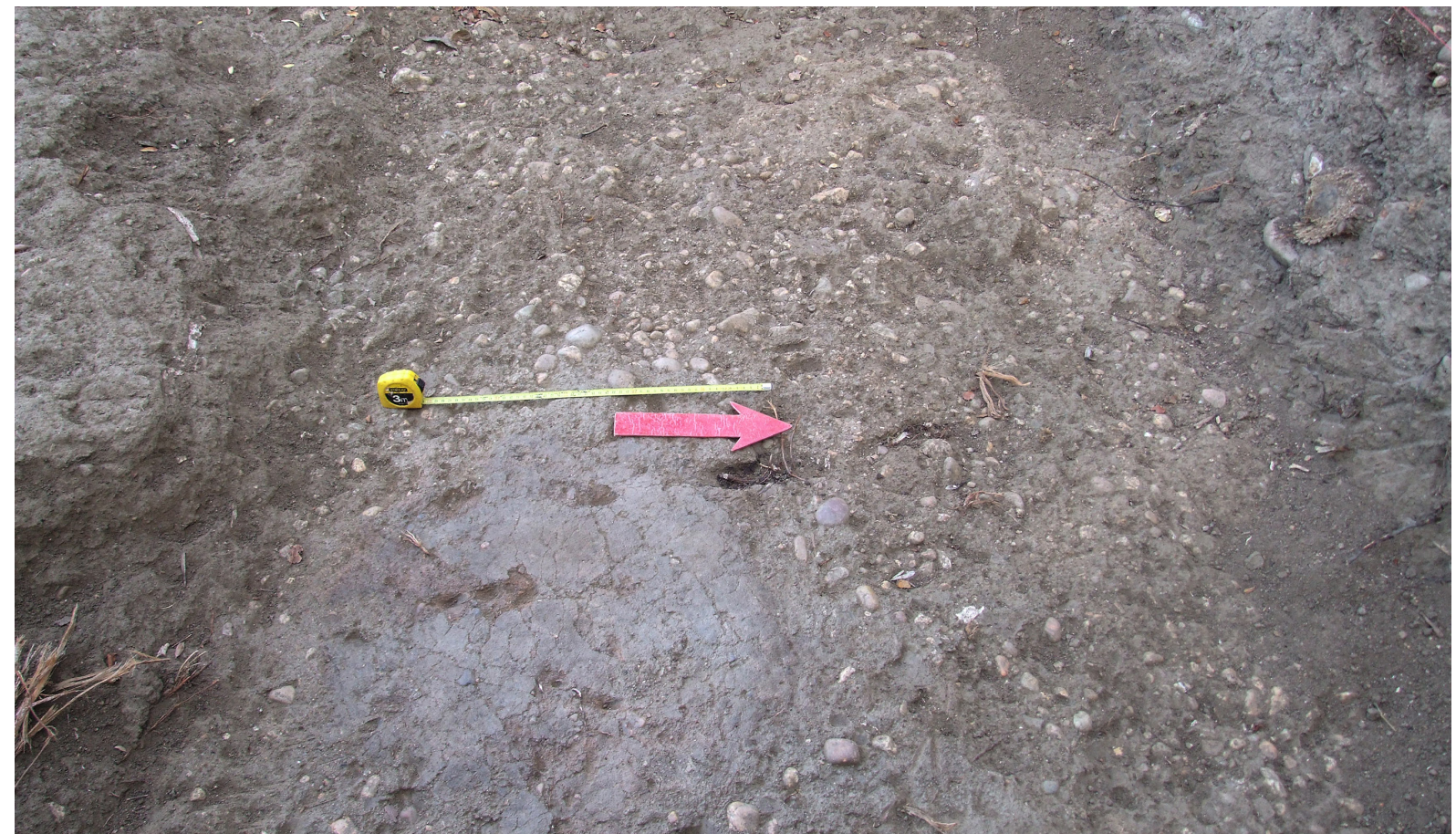

Figura 9. Estrutura de combustão [203] da sondagem 3 (fotografia de Carlos Pereira).

ISSN: 1133-4525 ISSN-e: 2255-3924 


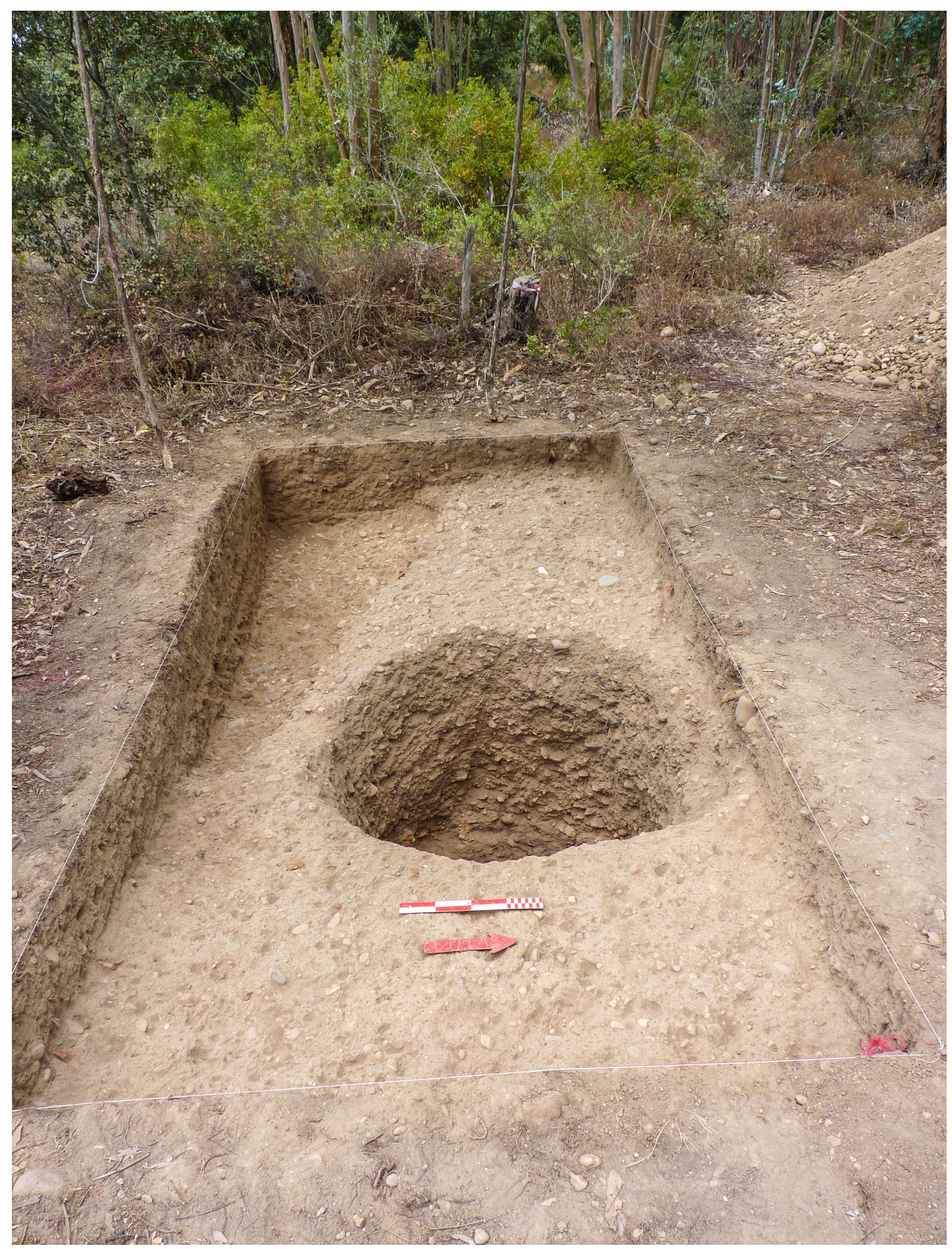

Figura 10. Fossa detectada na sondagem 1 no interior da qual se recolheram materiais islâmicos (fotografia de Rui Soares).

ISSN: 1133-4525 ISSN-e: 2255-3924 


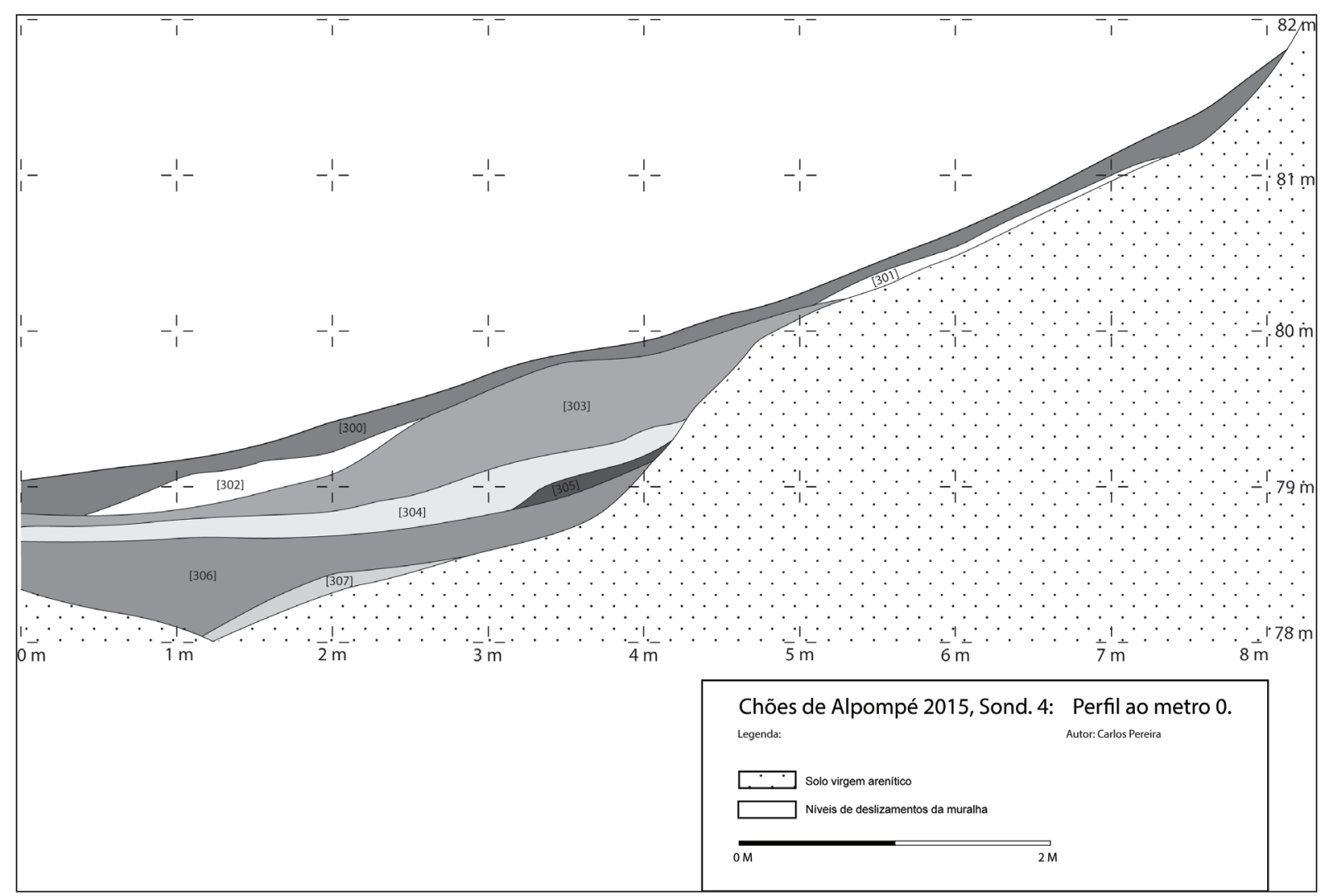

Figura 11. Perfil da estratigrafia da sondagem 4, realizada no exterior da muralha.

não foi absolutamente comprovada. Contudo, ficaram evidenciados profundos trabalhos de movimentação de terras, relacionados com a protecção do sítio, concretamente a depressão escavada em época republicana, que, no entanto, não corresponde a um fosso típico. Assim, parece evidente que o típico sistema de vallum foi aqui utilizado, ainda que não cumprindo com a tradicional tipificação dos acampamentos republicanos.

Os trabalhos de acompanhamento da desmatagem deixaram visível grandes tramos do ager. Este apresenta-se muito bem conservado, sendo visível em vários troços a estrutura muralhada em positivo. Trata-se de uma muralha de terra que, possivelmente, estaria constituída também por travejamentos de madeira.

Ficou ainda claro que a muralha de terra batida pode não rodear a totalidade da área do acampamento, uma vez que algumas vertentes são excessivamente abruptas, não sendo aí visíveis quaisquer restos do talude de terra.

Estruturas de âmbito doméstico datadas da Idade do Ferro foram reveladas na escavação das Sondagens 2 e 3. Trata-se sobretudo de solos de ocupação, com lareiras compostas por placas de argila, e/ ou fragmentos cerâmicos dispostos horizontalmente, por vezes assentes sobre uma base de pequenos seixos rolados (fig. 12). A última das sondagens, como já antes referimos, revelou estruturas negativas de tipo fossa, cuja interpretação funcional não se afigura fácil, até porque parece evidente que estariam associadas a outras realidades arqueológicas que se estendiam para a zona da extracção de saibro, portanto, destruídas no século passado. Uma delas pode tratar-se de uma fossa de evacuação de detritos domésticos, mas o mesmo uso é difícil de assumir para a outra, maior, que continha uma elevada quantidade de blocos de argila com negativos de ramagens, habitualmente designados por "cerâmica de revestimento". Este facto, associado à morfologia da própria estrutura, permite avançar com a hipótese de estarmos perante o que resta de um "fundo de cabana". Todavia, a cronologia dos materiais recolhidos no seu interior, centrada nos séculos VII/VI a.n.e., aponta para um momento em que as construções eram, na mesma região, já ortogonais, como acontece na Alcáçova de Santarém (Arruda $1993 ; 1999 / 2000)$. 


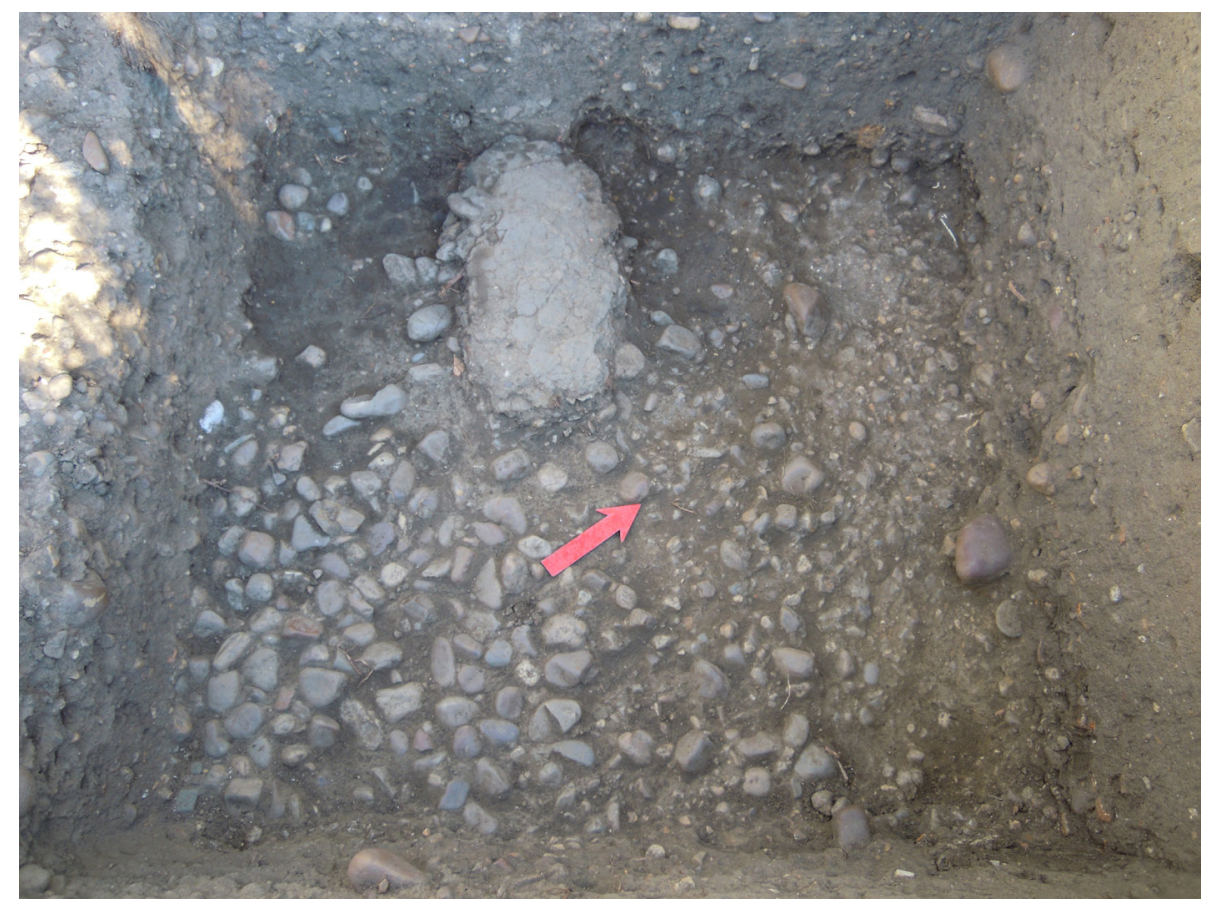

Figura 12. Estrutura de combustão identificada na sondagem 2 (U.E. [107]) (fotografia de Elisa de Sousa).

\subsection{Os materiais}

\subsubsection{A I Idade do Ferro}

O conjunto artefactual recuperado nos níveis mais antigos da ocupação da Idade do Ferro, apenas detectados na Sondagem 3, datáveis em torno ao século VII ou VI a.n.e., assume um claro carácter orientalizante, partilhando fortes semelhanças com outros já conhecidos no território imediato, como é, por exemplo, o caso da Alcáçova de Santarém (Arruda 1993, 1999-2000) ou do Alto do Castelo (Arruda et al. 2014).

A maioria dos fragmentos integra-se na categoria de cerâmica comum, correspondendo sobretudo a formas abertas, em concreto tigelas de perfil semi-hemisférico com bordo engrossado interiormente (fig. $13-\mathrm{n}^{\circ} 1 \mathrm{a}$ 5; fig. $14-$ n. $^{\circ} 25$ a 27 ) e a outros recipientes similares, que se distinguem, contudo, por exibirem um bordo mais aplanado (fig. $13-$ n. $^{\circ} 6$ a 11). Deve assinalar-se que algumas destas peças exibem as superfícies cuidadosamente polidas, indicando que terão formado parte do serviço de mesa. Os vasos fechados são menos frequentes tendo-se identificado apenas alguns recipientes de bordo simples, esvertido e colo curto e ligeiramente estrangulado, que, atendendo ao facto de exibirem marcas de exposição ao fogo na sua superfície exterior, podem ter sido utilizados na confecção de alimentos (fig. $13-$ n. $^{\circ} 12$ a 14; fig. $14-$ n. $^{\circ} 28$ ). Com efeito, e tal como já foi identificado em outras áreas do estuário do Tejo, o fabrico deste tipo de recipientes é intencionalmente mais grosseiro, com menor grau de depuração e maior integração de elementos não plásticos de dimensões superiores, que possibilitariam uma maior resistência a temperaturas elevadas.

Outros vasos fechados, de bordo esvertido e colo alto, revestidos com um engobe ou aguada esbranquiçada, sobre a qual foram aplicadas uma ou mais bandas vermelhas, foram também identificados, sendo facilmente classificáveis como pithoi (fig. 13 - n. ${ }^{\circ} 15$; fig. $14-$ n. $\left.{ }^{\circ} 29\right)$. A esta mesma forma poderão pertencer alguns fragmentos de asas de secção bífida também recolhidos. Neste grupo, poderá também incluir-se um outro fragmento de bordo esvertido e colo alto (fig. 13 - n. ${ }^{\circ}$ 16). Abundantes são também os fragmentos de parede com pintura na superfície externa, geralmente em tons de vermelho e negro, aplicada sobre um engobe branco, formando por vezes um padrão reticulado (fig. $14-\mathrm{n}^{\circ}{ }^{\mathrm{o}} 30$ ), e que possivelmente corresponderiam a este mesmo tipo de vasos.

A cerâmica cinzenta está também bem representada no conjunto, englobando maioritariamente tigelas de perfil semi-hesmisférico e bordo ligeiramente engrossado (fig. 13 - n. ${ }^{\circ} 17$ a 21; fig. $14-$ n. 31 a 37), ou de paredes rectilíneas (fig. $14-\mathrm{n}^{\circ} 38$ a 39). No entanto, recipientes mais profundos e de menor diâmetro, correspondentes a taças, foram também identificados 


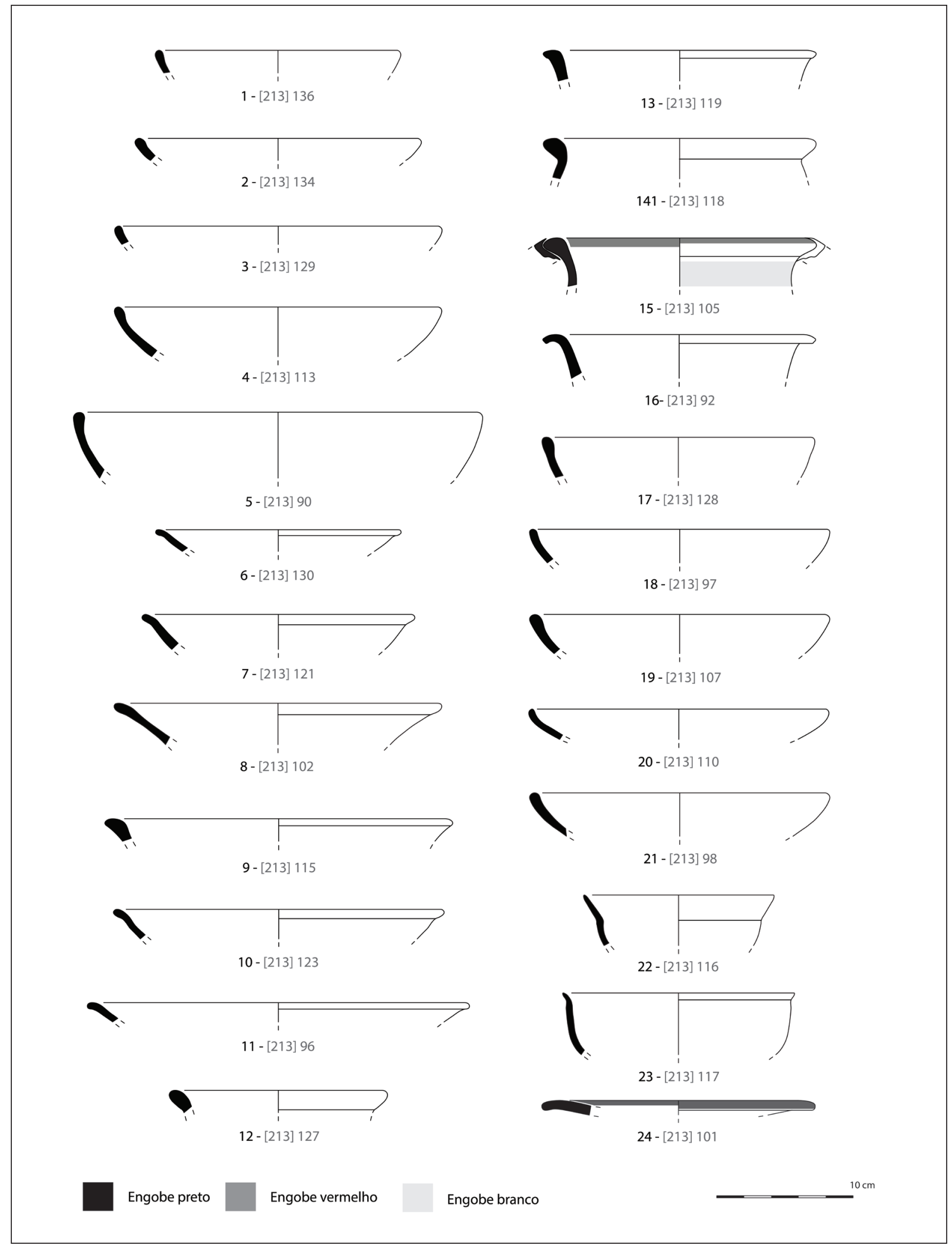

Figura 13. Materiais recuperados na U.E. [213]. 
(fig. $13-$ n. $^{\circ} 22$ a 23). Outros fragmentos, com bordo alto, simples e de tendência vertical ou ligeiramente esvasados, podem ter pertencido a pequenos potes (fig. $14-$ n. $^{\circ} 40$ a 47).

A cerâmica de engobe vermelho é uma das categorias menos bem representadas, contando com apenas um fragmento de um prato (fig. $13-\mathrm{n} .^{\circ} 24$ ), com bordo simples e aplanado, revestido apenas na superfície interna. Ainda assim, e por razões óbvias, o seu aparecimento merece destaque.

As ânforas são também raras, tendo sido possível documentar um único bordo de uma ânfora do tipo 1 do estuário do Tejo (Sousa e Pimenta 2014), com engobe branco na área externa (fig. $14-n .^{\circ} 50$ ).

Por último, resta referir a escassa representatividade de vasos de produção manual, nos quais se incluem apenas alguns bordos de vasos de perfil em S (fig. $15-$ 51 a 56), por vezes com bordo assinalado, alguns fragmentos de fundo (fig. $15-\mathrm{n} .^{\circ} 57$ e 58) e uma parede com aplicação de mamilo (fig. $15-n .^{\circ} 59$ ).

A maioria dos fragmentos recuperados de cerâmica comum, pintada, cinzenta e de engobe vermelho exibe características de fabrico muito similares às detectadas na foz do estuário do Tejo. Contudo, alguns fragmentos da primeira das categorias, em concreto algumas tigelas, apresentam um menor grau de depuração no seu fabrico, podendo, eventualmente, corresponder a produções locais.

\subsubsection{A II Idade do Ferro}

Nos níveis associados à lareira mais antiga documentada na Sondagem 3 foi possível recolher um pequeno conjunto de materiais que poderiam ser datados, grosso modo, em torno aos meados do $1^{\circ}$ milénio a.n.e.

Entre estes, destaca-se, em primeiro lugar, o bordo de uma ânfora (fig. $15-$ n. $^{\circ}$ 68) facilmente integrável no tipo 2 do estuário do Tejo (Sousa e Pimenta 2014: $\mathrm{n}^{\circ} 79$ ).

A cerâmica cinzenta, por sua vez, continua a ser frequente nesta fase, integrando formas similares às detectadas anteriormente (tigelas de perfil semi-hemisférico de bordo engrossado do tipo 1Aa (fig. $15-$ n. $^{\circ}$ 65) e pequenos potes do tipo $3 \mathrm{Ba}$ (fig. $15-\mathrm{n}^{\circ} 66$ e 67) da Rua dos Correeiros (Sousa 2014).

A cerâmica comum está também bem representada no conjunto, contando com algumas tigelas, de bordo engrossado internamente (fig. $15-$ n. $^{\circ}$ 60) ou aplanado (fig. $15-$ n. $^{\circ} 61$ ), e alguns vasos fechados, com colo curto e bordo pendente, assimiláveis ao tipo $10 \mathrm{Ba}$ (fig. $15-$ n. $^{\circ}$ n. ${ }^{\circ}$ 64), e com bordo esvertido e de perfil simples, do tipo 10Aa (fig. $15-$ n. $^{\circ}$ 62). Estas últimas correspondem, quase seguramente, a panelas, considerando as marcas de exposição ao fogo que exibem na superfície externa. As pastas destes recipientes recordam, mais uma vez, as produções identificadas na área de Lisboa (Grupo I e III da cerâmica comum da Rua dos Correeiros - Sousa 2014).

No entanto, e ao contrário do que se observa durante o período anterior, os vasos que podem corresponder a produções locais são agora bastante mais abundantes, englobando formas semelhantes às verificadas anteriormente (tigelas de bordo aplanado e vasos de colo longo e bordo assinalado exteriormente - fig. $15-\mathrm{n} .{ }^{\circ}$ 63). A cerâmica manual é também mais recorrente, verificando-se sobretudo o fabrico de vasos fechados com bordo esvertido e mais vertical (fig. $15-\mathrm{n} .^{\circ} 69$ e 70).

Este aumento do peso percentual das produções locais torna-se ainda mais evidente nos níveis associados à lareira mais recente detectada na Sondagem 3, observando-se também uma alteração nas características de fabrico. Com efeito, as pastas destas produções tornam-se agora mais porosas, com a inclusão de elementos não plásticos de maiores dimensões, exibindo um menor cuidado no seu acabamento, sendo as suas superfícies bastante grosseiras. Estas produções, que se tornam, agora, claramente maioritárias, abrangem, contudo, uma maior diversidade formal, em concreto grandes recipientes de bordo esvertido e aplanado (fig. 16, n. ${ }^{\circ} 80$ a 87), potes de perfil em $\mathrm{S}$ (fig. 15, $\mathrm{n}^{\mathrm{o}} 74,75$ ) e outros com colos algo desenvolvidos e bordo assinalado externamente (fig. $15, \mathrm{n}^{\mathrm{o}} 73$; fig. 16, n. ${ }^{\circ} 88$ ). Contudo, alguns vasos com produção um pouco mais cuidada, também de provável origem local/regional, foram também recuperados, devendo aqui assinalar-se a presença de tigelas (fig. 16, n. ${ }^{\circ} 78$ a 79) e a identificação de alguns fragmentos de paredes com decoração incisa na parede externa (fig. 16, $\mathrm{n}^{\circ}$ 92).

As cerâmicas manuais são, contudo, escassas, contando com apenas uma tigela (fig. 16, n. ${ }^{\circ}$ 95), alguns vasos com bordo evertido e assinalado, de superfícies grosseiras (fig. 16, n⿳ 96 a 98), paredes com decoração mamilar (fig. 15, n. ${ }^{\circ}$ 76) e fundos aplanados (fig. 16, n. $\left.^{\circ} 77\right)$.

O mesmo ocorre com a cerâmica cinzenta, estando esta representada por apenas alguns fragmentos de tigelas do tipo $1 \mathrm{Aa}$ e $1 \mathrm{Ac}$ (fig. 16, n. ${ }^{\circ}$ 93), uma carena provavelmente pertencente a um prato do tipo $2 \mathrm{Ba}$ (fig. $15, \mathrm{n}^{\mathrm{o}} 72$ ) e um pequeno pote do tipo $3 \mathrm{Ba}$ (fig. 15 , n. ${ }^{\circ}$ 71) da tipologia estabelecida para o estuário do Tejo (Sousa 2014), para além de um fragmento de fundo (fig. 16, n. ${ }^{\circ}$ 94). 


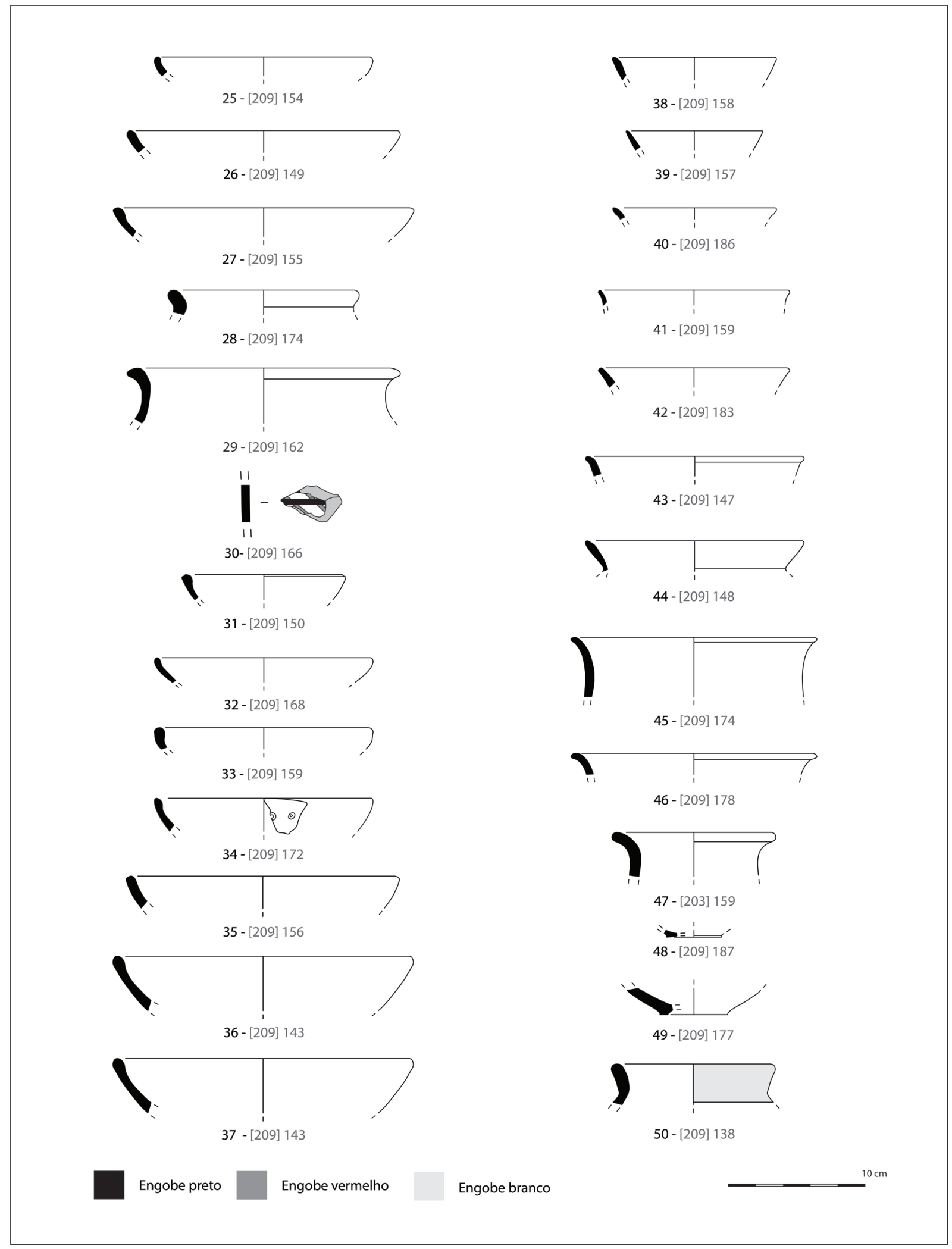

Figura 14. Materiais recuperados na U.E. [209]. 
Por outro lado, os materiais presumivelmente importados da área mais a juzante do estuário do Tejo são, agora, mais escassos, contabilizando-se apenas um fragmento de bordo de ânfora (fig. 16, n. ${ }^{\circ}$ 99) que, tal como no momento anterior, se enquadra no tipo 2 do estuário do Tejo (Sousa e Pimenta 2014). Contudo, o poder aquisitivo das comunidades que habitaram este sítio encontra-se atestado pela recolha de dois fragmentos de cerâmica ática de figuras vermelhas (fig. 16, $\mathrm{n}^{\circ}$ 100 e 101), pertencentes a kylikes, datáveis da primeira metade do século IV a.n.e., mais concretamente do seu segundo quartel.

\subsubsection{A época romana}

Contrariamente ao que seria expectável, o conjunto artefactual de época romana-republicana é pouco variado em termos de categorias morfo-funcionais.

No âmbito dos contentores anfóricos, pouco há a acrescentar aos dados já conhecidos, resultantes das inúmeras campanhas de prospecções que foram efectuadas no local. Os fragmentos de ânforas de produção itálica são muito frequentes nos níveis conservados de época romana-republicana, mas, infelizmente, são raros os exemplares classificáveis. Com efeito, documentaram-se apenas alguns escassos fragmentos de bordo do tipo Dressel 1A (fig. 17, n. ${ }^{\circ}$ 102), recolhidos na Sondagem 2, e de um outro exemplar provavelmente de idêntica tipologia, mas de origem adriática (fig. 18), que foi reutilizado no sistema de drenagem documentado nessa mesma sondagem. Outras produções anfóricas são mais raras, tendo sido recolhidos apenas alguns fragmentos de ânforas incluíveis nos tipos Maña C2 (T-7.4.3.2 ou T-7.4.3.3), de origem gaditana (fig. 17, n. ${ }^{\circ} 103$ e 104), e Castro Marim 1 importada do baixo Guadalquivir.

Por outro lado, a cerâmica de mesa é francamente escassa, resumindo-se apenas a um fragmento de cerâmica campaniense, possivelmente de produção calena e a um outro, recolhido em prospecção, de campaniense A (fig. 17, n. ${ }^{\circ} 105$ ). Deve, contudo, assinalar-se a recolha de alguns fragmentos de cerâmica cinzenta, decorados no exterior (fig. $17, \mathrm{n}^{\circ}$ 109 e 110), que podem pertencer a um tipo de jarro de produção cuidada muito característico da área do baixo Tejo, durante o período romano-republicano (Pimenta, Calado e Leitão 2014).

A maioria do conjunto artefactual da fase romana-republicana é formada por recipientes de cerâmica comum (fig. 17, n. $^{\circ} 106$ e 107) e cinzenta (fig. 17, n. ${ }^{\circ} 108$ ) muito semelhantes, quer em termos de fabrico quer no que se refere à morfologia, aos documentados nos níveis sidéricos mais tardios. Um cossoiro foi também recolhido (fig. 17, n. ${ }^{\circ} 111$ ).

Para além dos fragmentos cerâmicos, os trabalhos de escavação proporcionaram a recolha, nos níveis romanos, de alguns fragmentos de mó, manuais, de pequena dimensão, de granito de grão médio e fino. À superfície do terreno este tipo de artefacto é muito abundante.

Nos trabalhos de acompanhamento da desmatação das vertentes, foi encontrado um ponderal (fig. 19), que, apesar de não ter contexto arqueológico seguro, pode, muito provavelmente, integrar-se na época romana. É de cobre ou bronze, possui forma de disco, com um diâmetro de $3,3 \mathrm{~cm}$, e pesa 10 gramas. É idêntico, em todos os seus aspectos, a outros encontrados em trabalhos anteriores, que foram publicados, recentemente (Fabião, Pereira e Pimenta 2015).

A presença de materiais de construção de época romana à superfície deve também ser referida. Trata-se de fragmentos de tegulae e de um tijolo romboidal (fig. 20), este último idêntico a outro recolhido nos anos 60 pela equipa dos Serviços Geológicos de Portugal (Zbyszweski, Ferreira e Santos 1968). Lembre-se a este propósito que os pavimentos romanos de época republicana tipicamente itálicos, designados por opus spicatum, usam justamente este tipo de tijolo (Pimenta 2013). Este tipo em particular tem sido frequentemente associado, no Ocidente, a ocupações militares romano-republicanas, como acontece em Cáceres el Viejo (U1bert 1984), Monte dos Castelinhos (Pimenta 2013) ou Alto dos Cacos (Pimenta, Henriques e Mendes 2012: 273, figura 16).

A existência, à superfície do planalto dos Chões de Alpompé, de fragmentos de tegulae é, desde há muito, conhecida (Diogo e Trindade 1993-94). Apresentam um perfil relativamente incomum, com um ângulo praticamente recto. Sabemos bem que a atribuição de uma cronologia a este tipo de material de construção, sem o devido enquadramento estratigráfico, é problemática. Porém, trabalhos recentes em sítios da Citerior têm vindo a comprovar a sua utilização precoce, desde o século II a.n.e., em locais com presença militar (Rodrigo et al. 2013; Rodrigo, Carreras e Pera 2014: 199). Para o vale do Tejo, os recentes trabalhos de investigação em Monte dos Castelinhos, Vila Franca de Xira, atestam, de forma inequívoca, a utilização de telhados de tegulae em edifícios do século I a.n.e. (Pimenta 2013). 


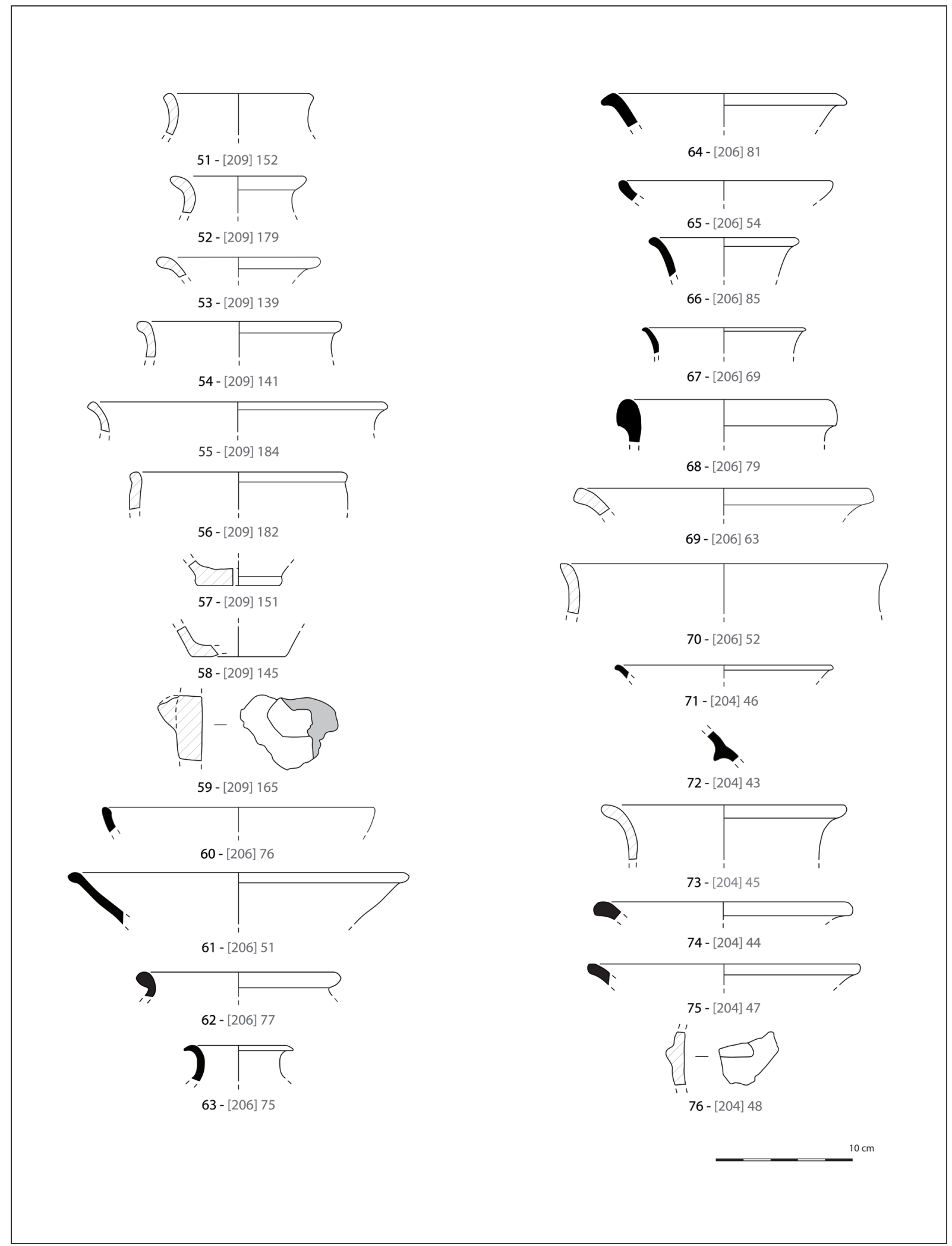

Figura 15. Materiais recuperados na U.E. [209], [206] e [204]. 


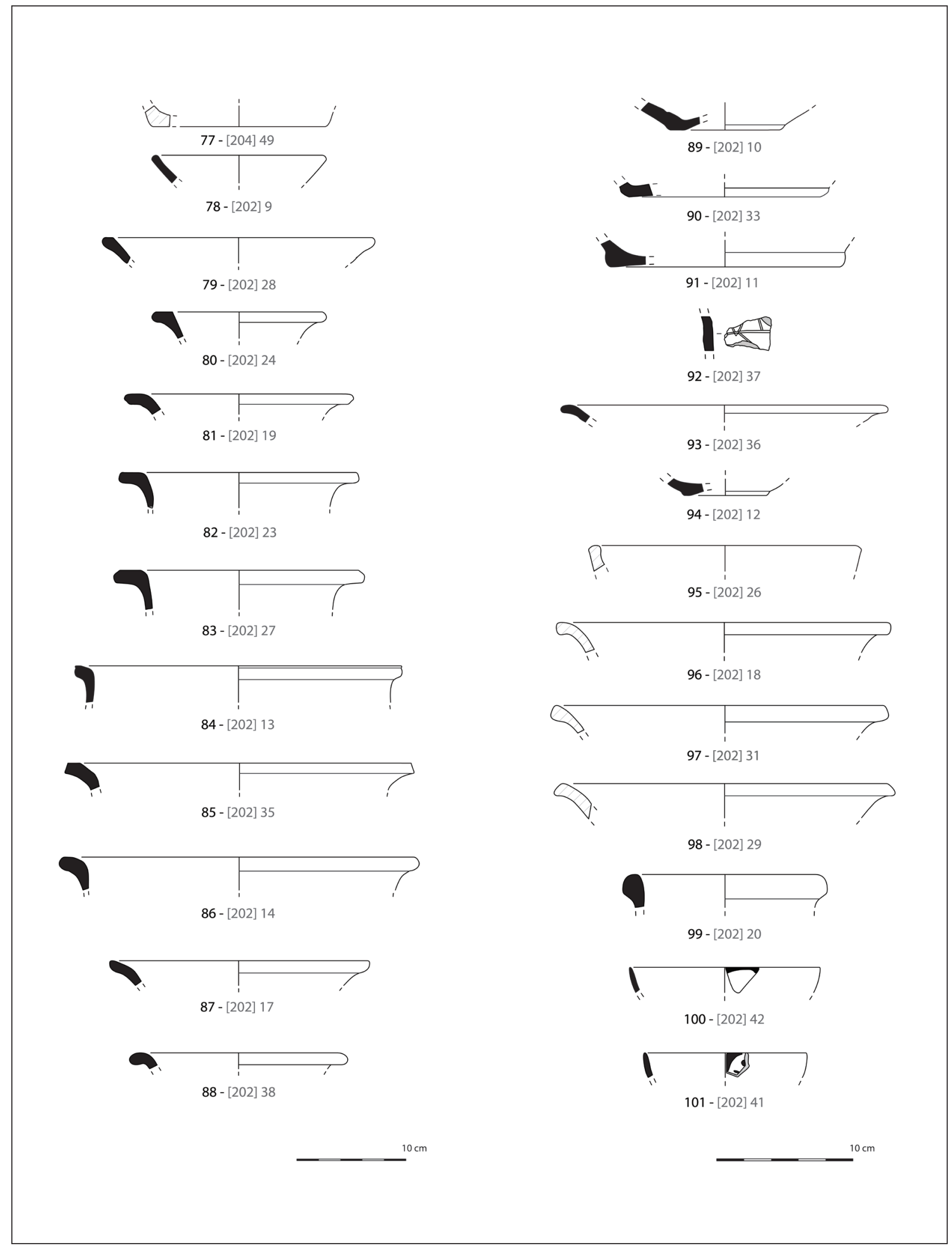

Figura 16. Materiais recuperados na U.E. [204] e [202]. 


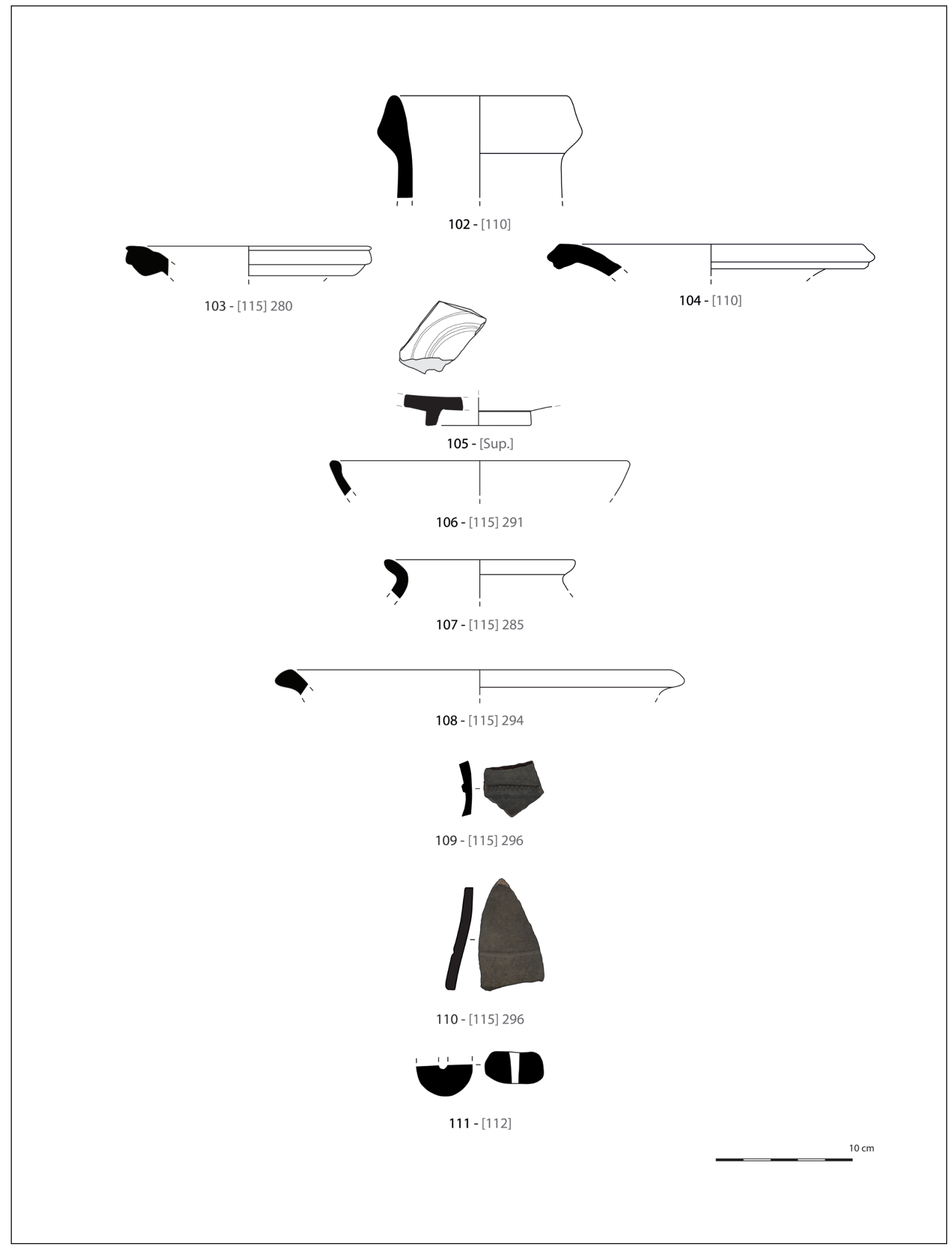

Figura 17. Materiais recuperados na U.E. [115], [112] e [110]. 


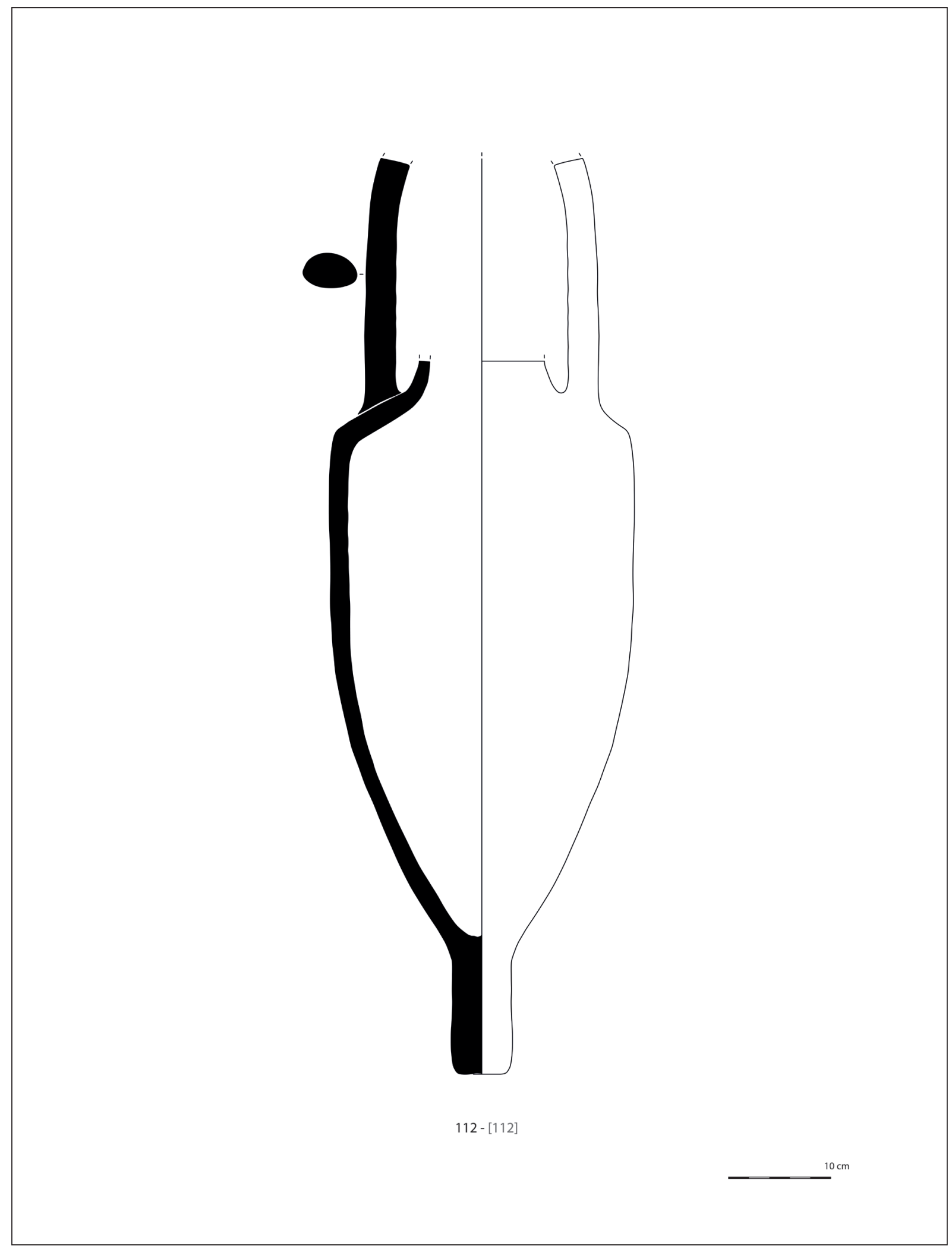

Figura 18. Materiais recuperados na U.E. [112]. 


\subsubsection{Outros}

As contas de colar de vidro azul recuperadas na Sondagem 1 são difíceis de datar uma vez que eram provenientes de níveis superficiais e/ou revolvidos. Podem pertencer, indistintamente, à Idade do Ferro ou à época romana, uma vez que não apresentam nenhuma característica particular que lhes dê uma maior consistência do ponto de vista cronológico. São esféricas e monocromas.

\subsubsection{A fauna}

O conjunto faunístico de Chões de Alpompé é bastante reduzido e diz respeito apenas à Idade do Ferro. A má preservação do material osteológico pode ser responsabilizada pela escassa dimensão da amostra, preservação que era particularmente grave nos níveis correspondentes à ocupação romana, cujos restos não se conservaram ou não permitiram, em absoluto, qualquer tipo de análise.

São apenas 26 os restos identificados de mamíferos a que se somam cinco fragmentos de bivalves de água doce (cf. Margaritifera sp.).

Note-se que os restos listados nas tabelas 1 (espécies presentes) e 2 (partes do esqueleto) são aqueles que foram registados segundo a metodologia de Davis (1992). Para além desses, outros poucos restos são identificáveis ao nível da espécie, nomeadamente três dentes superiores de Bos sp., um metatarso proximal e uma falange II da mesma espécie.

Quanto aos invertebrados, foram recuperados nos níveis da primeira Idade do Ferro alguns, poucos, vestígios de mexilhão-de-rio ( $c f$. Margaritifera sp.), um bivalve de água doce, recolhido, provavelmente, em algum afluente próximo do sítio.

A espécie mais frequente é claramente o gado bovino, constituindo quase metade dos restos da $2^{\mathrm{a}}$ Idade do Ferro e a totalidade dos de mamíferos da $1^{\mathrm{a}}$ Idade do Ferro.

Embora se trate uma amostra muito pequena, é certo que esta espécie teve um papel relevante nestes contextos.

Não foram observadas peças com marcas de corte. No entanto, é muito provável que os restos presentes sejam resultado de desperdícios domésticos provenientes do consumo destes animais pelas populações que produziram aqueles depósitos.

O gado bovino pode ter ainda outro tipo de utilizações para além do fornecimento de carne, nomeadamente o de servir no transporte de bens, pessoas e alfaias agrícolas, podendo ainda produzir leite. A única mandíbula encontrada apresentava um terceiro molar com algum desgaste, revelando a presença de um
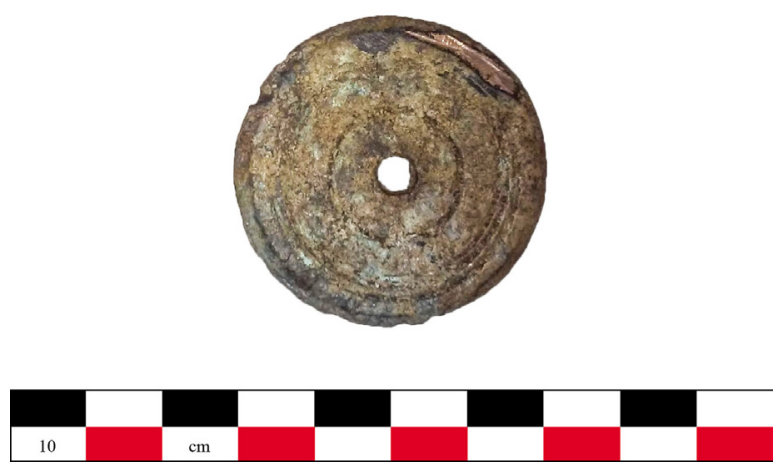

Figura 19. Ponderal recuperado durante o acompanhamento da desmatagem.
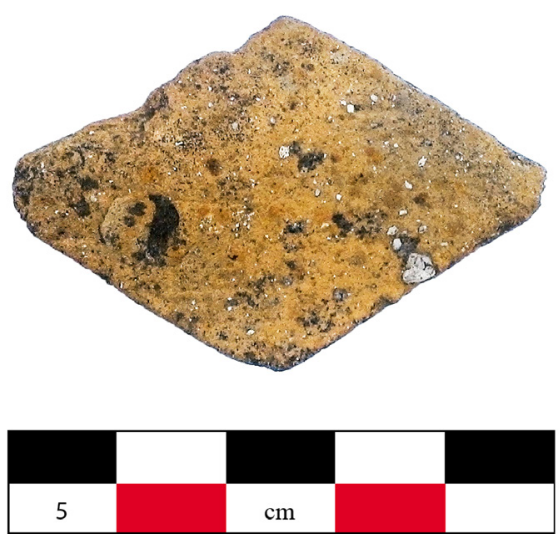

Figura 20. Tijolo romboidal recolhido à superfície.

animal relativamente velho, provavelmente com uma utilização secundária e abatido para consumo quando deixou de ser útil.

Os caprinos também parecem abundantes, tal como é usual desde o Neolítico, podendo ter sido usados para consumo da sua carne, leite ou lã.

Os suídeos estão representados no caso de Chões de Alpompé por apenas um dente, elemento que resiste normalmente mais à erosão dos solos. Os suídeos terão vindo, portanto, em terceiro ou quarto nas preferências alimentares destas pessoas.

Por fim, a presença de veado é relevante tendo em conta o conjunto, mas apenas demonstrada por quatro restos, talvez originados por apenas um animal. No entanto, a caça de grande porte era praticada e este grupo teria sofisticação suficiente para caçar animais como estes.

Ao compararmos este conjunto com outros restos do mesmo período e da mesma região verificamos que não se observam padrões muito uniformes no consumo destas espécies na Idade do Ferro (Valenzuela e Detry 2017). 
A Alcáçova de Santarém, o sítio contemporâneo mais importante, apresenta uma maior percentagem de caprinos entre os restos datados da Idade do Ferro (Davis 2006). Ainda mais acentuada é a presença de caprinos nos sítios contemporâneos de Castro Marim (Davis 2007), Monte Molião (Detry e Arruda 2013) e Mesas do Castelinho (Valenzuela e Fabião 2012).

Os conjuntos faunísticos do Núcleo Arqueológico da Rua dos Correeiros (Detry, Cardoso e Bugalhão 2016), na baixa de Lisboa, e do Cabeço do Guião (Arruda et al. no prelo), no baixo Vale do Tejo, ambos datados da Idade do Ferro, são os únicos a apresentar como espécie mais frequente o gado bovino. No entanto, ao contrário dos restos da Rua dos Correeiros, no Cabeço do Guião foi registado veado, tal como em Chões de Alpompé, resultado de estarem ambos em regiões com menor densidade humana e por isso com maior acesso a espécies selvagens.

O conjunto faunístico de Chões de Alpompé é claramente muito afectado pela má preservação, resultado de más condições geológicas para o efeito. Esta comunidade, que habitou durante o primeiro milénio a.n.e. no vale do Tejo, terá dependido sobretudo das espécies domésticas que produziam carne e produtos secundários, completando a sua alimentação caçando espécies selvagens como o veado.

\section{DISCUSSÃO E CONSIDERAÇÕES FINAIS}

O debate científico acerca da associação de Chões de Alpompé à cidade de Moron, mencionada por Estrabão, e ao próprio acampamento romano de Décimo Júnio Bruto, apoiava-se, até ao momento, única e exclusivamente nos dados da topografia do terreno, nos materiais recolhidos à superfície e ainda na toponímia. Os resultados obtidos nos trabalhos arqueológicos efectuados em 2015 e 2016 permitem debater estas e outras questões com outros argumentos, mais sólidos, podendo ser o ponto de partida para um projecto mais ambicioso e metodologicamente mais organizado.

Embora tenhamos conhecimento da existência de elementos provenientes de recolhas de superfície que permitem assumir que o planalto foi ocupado durante o Paleolítico, o Calcolítico e a Idade do Bronze, a totalidade dos dados obtidos nos trabalhos de escavação remetem apenas para as instalações da Idade do Ferro e da época Romana, que foram seguramente mais intensas. Contudo, houve oportunidade de recolher à superfície do terreno um machado de pedra polida (fig. 21) que, conjuntamente com outros materiais, evidenciam a presença de grupos humanos no local, pelo menos, durante o $3^{\circ}$ milénio a.n.e.

Os dados que se referem à ocupação da Idade do Ferro dos Chões de Alpompé são talvez os mais importantes que os trabalhos de campo de 2015 proporcionaram. Esta importância advém não da sua existência, que já era conhecida por materiais resultantes de prospecções, mas da sua matriz orientalizante, especificamente dos mais antigos, recuperados na Sondagem 3. As características formais e de fabrico dos espólios recolhidos nos níveis mais profundos indicam uma relação profunda e directa com os recuperados na Alcáçova de Santarém e em outros sítios da área mais a norte do Estuário do Tejo, mas da margem esquerda, como o Alto dos Cacos (Almeirim) e o Alto do Castelo (Alpiarça), e que pode passar, inclusivamente, por centros de abastecimento únicos. Refira-se ainda que os quatro sítios mantêm entre si relações de absoluta visibilidade. O facto de os espólios dos níveis inferiores dos Chões de Alpompé serem, apesar de tudo, mais tardios do que os de Santarém, século VII e, sobretudo, VI a.n.e., parece autorizar a admissão de que esta ocupação resulta de um fenómeno de "colonização interna", talvez protagonizada pela comunidade que habitava no planalto scallabitano. Porém, a probabilidade de, nesta área do Tejo, o povoamento sidérico ter funcionado em rede, interfere com uma qualquer leitura de relações de subordinação, apoiando as de coordenação.

Muito importante parece ser também a situação detectada a partir de meados do milénio, quando a realidade artefactual ganha características próprias e consideravelmente distintas das observadas na Alcáçova de Santarém. Como se sabe, neste último sítio a matriz oriental mantém-se até aos alvores da romanização (Arruda 1993; 1999/2000). Aí, e apesar das morfologias dos recipientes evoluírem, a cerâmica cinzenta permanece como uma das mais bem representadas, os vasos de armazenamento são sempre de tipo pithos e a própria cerâmica comum apresenta, quase sempre, as superfícies engobadas e cuidadosamente polidas. Pelo contrário, nos Chões de Alpompé, o conteúdo dos inventários da $2^{\text {a }}$ fase da II Idade do Ferro deixa transparecer uma ruptura na relação previamente estabelecida, passando as produções locais, com fabricos de características muito próprias, a dominar. As próprias formas alteram-se tornando-se muito escassos os recipientes que se podem associar ao "orientalizante tardio", como a cerâmica cinzenta, ou os vasos pithoides. A ocupação humana dos Chões de Alpompé torna-se, a partir de meados do $1^{\circ}$ milénio a.n.e., aparentemente, autónoma, ganhando protagonismo próprio, ainda que, 
como é evidente, não estivesse completamente desligada da dos sítios localizados no território imediato, com quem, aliás, e como já referimos, mantinha relações de inter-visibilidade. Mas tudo indica uma crescente "desorientalização" e, talvez, uma maior ligação ao mundo do Tejo médio.

Independentemente desta situação, não podemos deixar de considerar que a existência de grupos humanos instalados no planalto dos Chões de Alpompé desde pelo menos a última centúria da $1^{\mathrm{a}}$ metade do $1^{\mathrm{o}}$ milénio a.n.e., associados a outros dados já de época republicana, pode ser considerado argumento suficiente para defender que Móron se localizou, efectivamente, neste local, correspondendo, assim, ao sítio onde Décimo Júnio Bruto instalou o seu acampamento.

À luz dos dados actuais, e tendo em consideração não só os resultados dos trabalhos de campo de 2015/16, mas também outros já conhecidos, concretamente os espólios metálicos que entram na categoria de militaria, como é o caso das glandes de chumbo, algumas produzidas no local (Fabião, Pereira e Pimenta 2015), parece indiscutível que o planalto dos Chões de Alpompé albergou, nos meados do terceiro quartel do século II a.n.e., um acampamento romano equipado com um sistema de defesa típico da época republicana - o ager.

Ainda assim, e no caso concreto do recinto militar, a irregularidade dos seus limites suscita algumas inquietações.

Efectivamente, o modelo clássico que é mencionado nos textos antigos (Políbio, Hist. p.e. 6.28; Higino, De Monitionibus Castrorum) refere acampamentos de planta ortogonal, geralmente quadrangulares ou rectangulares, atravessados por vias principais (praetoria e principalis) que se cruzam em frente ao quartel-general (praetoria ou principia) (Morillo Cerdán 2008: 78). Porém, deve ter-se em consideração que os acampamentos permanentes (castra stativa) ou de hibernação (castra hiberna) deveriam ser realidades consideravelmente distintas, do ponto de vista construtivo e da dinâmica de consumo, dos acampamentos "de campanha", como pode ter sido o caso, neste momento mais antigo, do planalto do Alviela. Também por este motivo recentemente se tem debatido acerca da pluralidade de vestígios e sobre a terminologia de contextos militares romanos (Morillo Cerdán 2014), nem sempre cumprindo com as normas da arquitectura militar.

O debate científico tem-se centrado também na dimensão temporal e na estabilidade dos recintos militares e nos seus reflexos na morfologia da sua construção (Morillo Cerdán 2008: 74-77; Sabugo Sousa 2007: 22).

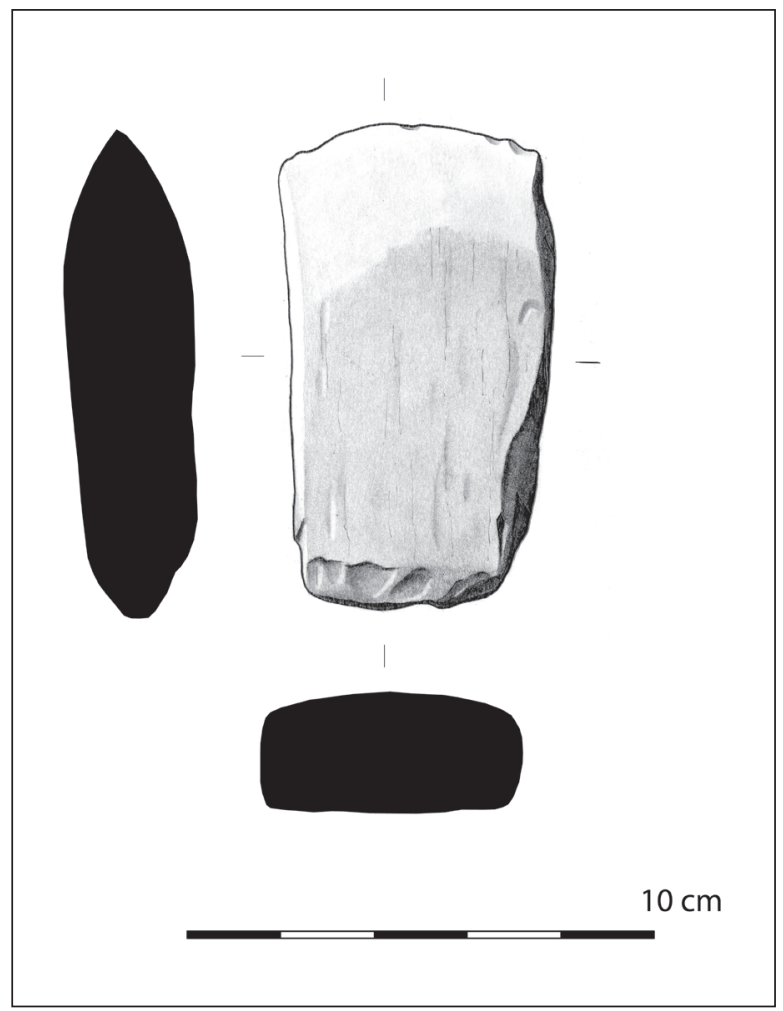

Figura 21. Machado de pedra polida.

É inegável que os primeiros estão directamente relacionados entre si e que se materializam nas construções militares. Quanto maior a necessidade de permanência no terreno, maior a necessidade de estruturas defensivas capazes de resistir ao tempo e a possíveis investidas do inimigo. Por outro lado, não é de descartar que a tipologia dos recintos estivesse igualmente associada à estratégia militar, ou seja, que cada recinto se adaptasse à maior ou menor proximidade do inimigo, aos objectivos concretos (defesa, ataque, controlo, abastecimento e/ou apoio de retaguarda a outros acampamentos, entre outros) ou à celeridade da campanha.

Contrariamente aos castra stativa ou aos castra hiberna (César, Bellum Gallicum, V, 24; VI, 32; VII, 32 e 90; VIII, 5; Hírcio, Bellum Gallicum, VIII, 5; Tito Lívio, XL, 33, 3), os recintos de campanha ou castra aestiva (Cícero, Ad Atticum., V, 17; Ad Familiares, II, 13; Suetónio, Claudio, 1; Divus Iulius, 49) deveriam apresentar características bem diferentes daqueles, sobretudo no que se refere à sua morfologia. A constante necessidade de mobilidade, a permanente movimentação dos exércitos e a circulação em território hostil obrigavam a que os recintos militares fossem fixados em espaços com condições estratégicas e de defensabilidade natural, aproveitando muitas vezes a topografia, 
adaptando-se às condições de implantação existentes. Refira-se, a título de exemplo, que, quando em marcha, os exércitos construíam cada dia acampamentos de pernoita, que eram utilizados para contar os dias de marcha (César, Bellum Gallicum, VII, 36; Tácito, Historias, III, 15; IV, 71; Plínio, V, 1), o que complica ainda mais o panorama da Arqueologia Militar Romana.

Esta situação terá fomentado a existência de recintos militares que apresentam plantas irregulares e vestígios arqueológicos mais ténues, quer do ponto de vista arquitectónico quer no que se refere aos espólios. Com efeito, já foi demonstrado arqueologicamente que a planta dos acampamentos nem sempre segue os critérios definidos nos textos clássicos (Morillo Cerdán 1991: 136), podendo defender-se que o esforço dedicado à construção do acampamento dependia das condições de segurança do território, assim como dos objectivos concretos para o qual era construído.

Infelizmente, as escavações nos Chões de Alpompé não foram suficientemente amplas em área para compreender, devidamente, o tipo de construções que poderão ter existido no sítio, para além do sistema defensivo construído apenas com terra obtida na área imediatamente exterior (fig. 22) e da estrutura de tipo fosso, de dimensões bastante reduzidas, que, provavelmente, não circundaria todo o planalto. A própria muralha de terra pode também não rodear a totalidade da área, uma vez que algumas vertentes são excessivamente abruptas, não sendo aí visíveis restos do talude de terra. Contudo, o sistema de drenagem identificado na Sondagem 2, por um lado, e os materiais de construção que se recolheram à superfície do terreno (tegulae e tijolos romboidais), por outro, podem indiciar a existência de construções de alguma envergadura que seriam compatíveis com um tipo de acampamento mais permanente.

Porém, e atendendo ao facto de parecer indesmentível a ocupação do lugar durante os dois primeiros decénios do século I a.n.e., e ainda tendo em consideração a escassa área escavada e a dificuldade de distinguir nos níveis identificados materiais associáveis a distintas fases republicanas (associadas à campanha de Décimo Júnio Bruto ou às guerras sertorianas), obriga-nos a ser cautelosos nas interpretações.

Ainda assim, pode adiantar-se que parece seguro que o planalto dos Chões de Alpompé foi usado para apoiar a "excursão" do Galaico ao Norte, constituindo-se, então, como um Acampamento de Campanha, que funcionou igualmente como recinto militar de retaguarda, situação que permite também supor que a área estaria moderadamente controlada nesta fase.
Recordamos que no ano imediatamente anterior Q. Servílio Cipião havia vencido as forças de Viriato e que Décimo Júnio "sufocou" algumas rebeliões de lusitanos em 138 a.n.e. (Veleio Patérculo, Historiae Romanae, II, 1-5). Porém, a situação deveria estar já relativamente bem controlada no Ocidente peninsular, motivo pelo qual o Senado romano, considerando o território lusitano submetido (Tito Lívio, Periocas, 55, 10), “encomenda" uma expedição às comunidades do Noroeste (Cavada Nieto 2009: 114).

Não podemos, portanto, deixar de insistir que a quantidade de cerâmicas de mesa e de cozinha é reduzida, sendo muito abundantes os contentores anfóricos. No caso dos Chões de Alpompé, as ânforas itálicas, concretamente greco-itálicas e Dressel 1, mas também outras com origem no norte de África e na Baía de Cádis (Pimenta e Arruda 2014), dominam em termos absolutos, sendo raríssima a cerâmica de mesa. As cerâmicas de mesa, como a campaniense ou a de paredes finas, que foram certamente usadas pelos militares que aqui se instalaram, foram transportadas no momento da partida, ao contrário das ânforas, que, vazias não tinham qualquer utilidade concreta, para além de representarem um peso considerável na bagagem a carregar. $\mathrm{O}$ mesmo se passa relativamente às muitas mós de pequena dimensão que foram abandonadas no sítio, que não eram exactamente transportáveis, para além de puderem ser facilmente substituídas.

Porém, uma ocupação restrita no tempo, concretamente centrada apenas em torno aos meados do $3^{\circ}$ quartel do século II a.n.e., não pode ser assumida para o planalto do Alviela. A verdade é que o conjunto numismático conhecido (Ruivo 1999) engloba moedas que atingem o reinado de Augusto, apesar de a grande maioria ser anterior a 80 a.n.e. Algumas ânforas (Dressel 2/4, Classe 67) permitem reconhecer também uma ocupação mais tardia, ainda que muito provavelmente também de âmbito militar. Uma relação directa dos Chões de Alpompé com os episódios bélicos do primeiro quartel do século I a.n.e. parece pois evidente, relação que aliás se integra bem na realidade do território a norte do Tejo. Com efeito, «...o seu abandono, parece ser pouco posterior a 81 a.C....e terá servido como guarda avançada de Metelo durante uma ofensiva realizada em 79 a.C. contra Sertório e seus aliados e depois abandonado» (Ruivo et al. 2015: 141).

Assim, não é impossível pensar que o local foi palco de várias ocupações de carácter militar, ainda que não necessariamente contínuas, devendo uma delas obrigatoriamente relacionar-se com as guerras sertorianas, a avaliar, sobretudo, pelo conjunto numismático. 


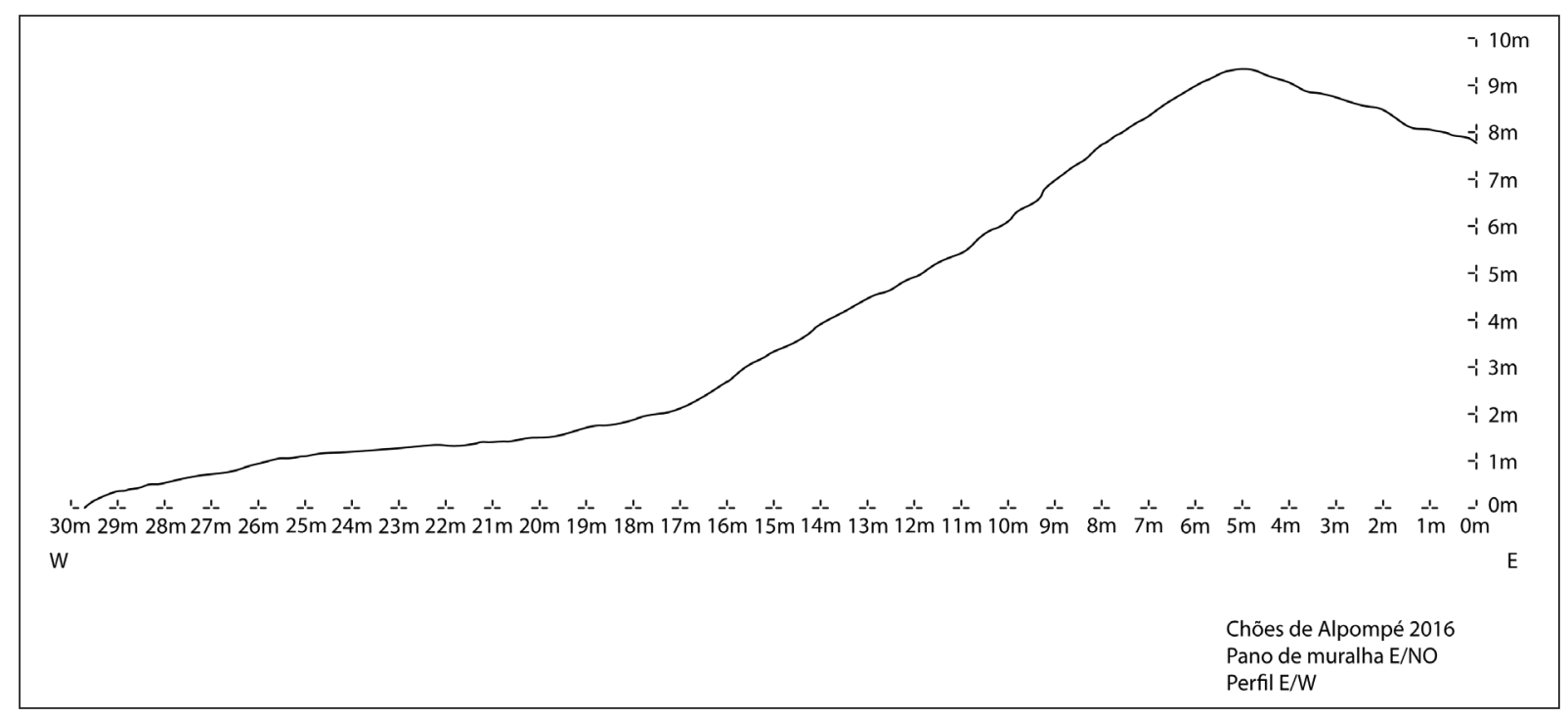

Figura 22. Perfil de um dos panos de muralha identificado durante os trabalhos de desmatagem.

Infelizmente, os trabalhos de campo de 2015 foram parcos no que se refere à ocupação republicana, não tendo sido possível detectar uma sobreposição de níveis desta fase.

Neste mesmo contexto, de sucessivas, mas não contínuas, ocupações militares temporárias, lembre-se também que o «...monte que chamão de Pompeio...», onde, de acordo com Duarte Nunes Leão, os militares liderados por Aben Iacob, Miramolim de Marrocos, se instalaram, em 1184, deve corresponder aos Chões de Alpompé.

Se o topónimo actual e o âmbito geográfico dos acontecimentos narrados na Crónica de Afonso Henriques apontam nesse mesmo sentido, os dados recuperados na Sondagem 1 são cronologicamente sincrónicos dos acontecimentos narrados na crónica de Afonso Henriques.

\section{Agradecimentos}

Trabalho realizado no âmbito do Projecto Fenícios no Estuário do Tejo (PTDC/EPH-ARQ/4901/2012).

\section{BIBLIOGRAFIA}

Alarcão, J. (1983): Portugal Romano. Lisboa, Editorial Verbo (3. ${ }^{\mathrm{a}}$ edição).

Alarcão, J. (2002): "Scallabis e o seu território", in De Scallabis a Santarém: 37-46. Lisboa, Museu Nacional de Arqueologia.
Arruda, A. M. (1993): “A ocupação da Idade do Ferro da Alcáçova de Santarém no contexto da expansão fenícia para a fachada atlântica peninsular". Estudos Orientais 4: 193-214.

Arruda, A. M. (1999-2000): Los fenicios en Portugal: Fenicios y mundo indigena en el Centro y sur de Portugal. Barcelona, Universidad Pompeu Fabra.

Arruda, A. M.; Pereira, C.; Sousa, E.; Pimenta, J. e Soares, R. (2015): Chões de Alpompé, 2015. Relatório Final. Lisboa, Relatório entregue à Direcção Geral do Património Cultural S-11870.

Arruda, A. M.; Sousa, E.; Pimenta, J.; Mendes, H. e Soares, R. (2014): “Alto do Castelo's Iron Age occupation (Alpiarça, Portugal)”. Zephyrus 74: 143-155. http://dx.doi.org/10.14201/zephyrus201474143155

Bargão, P. (2006): As importações anfóricas durante a época romana republicana Alcáçova de Santarém. Tese de Doutoramento, Universidade de Lisboa. Inédita. http://repositorio.ul.pt/handle/10451/447

Cavada Nieto, M. (2009): "Décimo Junio Bruto en Hispania: las fuentes literarias", in López Díaz, M. (coord.), Historia y Cultura. Estudios en homenaje al profesor José M. Pérez García: vol. I, 113-129. Vigo, Universidad de Vigo.

Davis, S. (1992): “A rapid method for recording information about mammal bones from archaeological sites". Ancient Monuments Laboratory Ancient Monuments Laboratory Report 19: 1-14.

Davis, S. (2006): Faunal remains from Alcáçova de Santarém (Portugal). Lisboa, Instituto Português de Arqueologia. 
Davis, S. (2007): The mammals and birds from the Iron Age and Roman periods of Castro Marim, Algarve, Portugal. Trabalhos do CIPA 107. Lisboa, Instituto Português de Arqueologia.

Detry, C. e Arruda, A.M. (2013): “A fauna da Idade do Ferro e Época romana de Monte Molião (Lagos, Algarve): continuidades e rupturas na dieta alimentar". Revista Portuguesa de Arqueologia 15: 215-227.

Detry, C.; Cardoso, J. L. e Bugalhão, J. (2016): “A alimentação em Lisboa no decurso da Idade do Ferro: resultados das escavações realizadas no núcleo arqueológico da rua dos correeiros (Lisboa, Portugal)". Spal 25: 67-82. http://dx.doi.org/10.12795/ spal.2016i25.03

Diogo, A. D. (1982): “A propósito de "Morón”. Estudo de alguns documentos provenientes dos Chões de Alpompé (Santarém)". Clio 4: 147-154.

Diogo, A. D. (1993): “Ânforas pré-romanas provenientes dos Chões de Alpompé". Estudos Orientais 4: 215-227.

Diogo, A. D. e Trindade, L. (1993-1994): "Materiais provenientes de Chões de Alpompé (Santarém)". Conímbriga 33: 263-281.

Fabião, C. (1989): Sobre as ânforas do acampamento Romano da Lomba do Canho (Arganil). Lisboa, Centro de Arqueologia da Universidade de Lisboa.

Fabião, C. (2014): "Por este rio acima: conquista e implantação romana no ocidente da península ibérica". Cira Arqueologia 3: 9-24.

Fabião, C.; Pereira, T. e Pimenta, J. (2015): “Coleção de metais do sítio arqueológico dos Chões de Alpompé - Santarém”. Cira Arqueologia 4: 110-150.

Ferreira, C. B.; Catarino, J. P. e Pinho, L. S. (1993): "Chões de Alpompé. Síntese cultural". Revista ESES 1: 55-63.

Girão, A. e Bairrão Oleiro, J. (1953): “Geografia e campos fortificados romanos". Boletim do Centro de Estudos Geográficos 7: 77-80.

Kalb, F. e Hock, M. (1988): “Moron”. Conimbriga 27: 189-201.

Mantas, V. (1986): “Arqueologia urbana e fotografia aérea: contributo para o estudo do urbanismo antigo de Santarém, Évora e Faro". Trabalhos de Arqueologia 3: 13-26.

Morillo Cerdán, A. (1991): "Fortificaciones campamentales de época romana en España”. Archivo Español de Arqueología 64: 135-190.

Morillo Cerdán, A. (2008): “Criterios arqueológicos de identificación de los campamentos romanos en Hispania". Salduie 8: 73-93.
Morillo Cerdán, A. (2014): "Modelos de arquitectura militar e implantación territorial de los campamentos republicanos en Hispania", in R. Mataloto, V. Mayoral Herrera e C. Roque (eds.), La gestación de los paisajes rurales entre la protohistoria y el período romano. Formas de asentamiento y procesos de implantación: 227-252. Mérida, CSIC.

Pimenta, J. (2005): As ânforas romanas do Castelo de São Jorge (Lisboa). Lisboa, Instituto Português de Arqueologia.

Pimenta, J. (2013): “A Arquitetura do Monte dos Castelinhos", in Catálogo Exposição Monte dos Castelinhos (Castanheira do Ribatejo): Vila Franca de Xira e a conquista romana no Vale do Tejo: 31-42. Vila Franca de Xira, Câmara Municipal.

Pimenta, J.; Henriques, E. e Mendes, H. (2012): $O$ acampamento romano de Alto dos Cacos - Almeirim. Almeirim, Câmara Municipal.

Pimenta, J. e Arruda, A. M. (2014): "Novos dados para o estudo de Chões de Alpompé (Santarém)". Estudos Arqueológicos de Oeiras 21: 375-392.

Pimenta, J.; Calado, M. e Leitão, M. (2014): "Novos dados sobre a ocupação pré-romana da cidade de Lisboa. A intervenção da Rua de São João da Praça", in A. M. Arruda (ed.), Fenícios e Púnicos por terra e mar 2: 712-723. Lisboa, Centro de Arqueologia da Universidade de Lisboa.

Ramon Torres, J. (1995): Las Ánforas Fenicio-Púnicas del Mediterráneo Central y Occidental. Barcelona, Universidad de Barcelona.

Ribera Lacomba, A. (1998): La fundació de Valencia. La ciutat a l'època romana repulicana (Segles II-I a. de C.). Valencia, Universidad de Valencia.

Ribera Lacomba, A. (2002): "El papel militar de la fundación de Valentia (138 a.n.e.): historia y arqueología", in A. Morillo Cerdán, F. Cadiou e D. Hourcade (coords.), Defensa y Territorio en Hispania de los Escipiones a Augusto (espacios urbanos y rurales y provinciales): 363-390. Madrid, Casa de Velázquez.

Rodrigo, E.; Gutiérrez García-Moreno, A.; Álvarez, A.; Pitarch, A.; Mercado, M. e Guitart, J. (2013): “El yacimiento de Can Tacó (Vallès Oriental, Cataluña) y el inicio de la arquitectura de tipo itálico en la Península Ibérica. Análisis de los materiales constructivos cerámicos (tegulae y imbrex)", in Actas del I Congreso Internacional sobre Estudios Cerámicos. Homenaje a la Dra. M. Vegas: 1572-1594. Cádiz (2010), Cádiz, Universidad de Cádiz.

Rodrigo, E.; Carreras, C. e Pera, J. (2014): "La presencia romana en el NE de la Provincia Citerior durante el siglo II A.C. Aproximación arqueológica a partir de 
los yacimientos de Can Tacó (Montmeló, Barcelona) y Puig Castellar (Biosca, Lleida)", in Actas da II Reunião Cientifica As Paisagens da Romanização - Fortins e ocupação do território no séc. II a.C. - I d. C.: 191-209. Redondo - Alandroal (2012), Madrid, CSIC.

Ruivo, J. (1997): "O conflito Sertoriano no Ocidente Hispânico: o testemunho dos tesouros monetários". Archivo Español de Arqueología 70: 91-100.

Ruivo, J. (1999): "Moedas do acampamento romano-republicano dos Chões de Alpompé (Santarém)", in R. Centeno, M. García-Bellido e G. Mora (eds.), Rutas, Ciudades y Moneda en Hispania. Actas del II Encuentro Peninsular de Numismática antigua: 101-110. Porto (1997), Madrid, CSIC.

Ruivo, J.; Sales, P.; Lourenço, S. e Barros, P. (2015): "O tesouro romano-republicano do Casal Ascenso Antunes (Ferreira do Zêzere, Santarém, Portugal)". Conímbriga 54: 133-156.

Sabugo Sousa, N. (2007): "Hispania: huellas de la conquista romana. Aproximación al estudio de los fosos de los asentamientos militares peninsulares". Estudios Humanísticos 6: 19-46.

Sousa, E. (2014): A ocupação pré-romana da foz do Estuário do Tejo. Lisboa, Centro de Arqueologia da Universidade de Lisboa.
Sousa, E. e Pimenta, J. (2014): “A produção de ânforas no Estuário do Tejo durante a Idade do Ferro", in R. Morais, A. Fernández e M. J. Sousa (eds.), As produções cerâmicas de imitação na Hispânia: 303315. Porto, Universidade do Porto.

Ulbert, G. (1984): Cáceres el viejo. Ein spätrepublikanisches Legionslager in Spanisch-Estremadura. Mainz-am-Rhein, Philipp von Zabern.

Valenzuela, S. e Fabião, C. (2012): “Ciervos, ovejas y vacas: el registo faunístico de Mesas do Castelinho (Almodôvar) entre la Edad del Hierro y época romana", in Actas V Encontro de Arqueologia do Sudoeste Peninsular: 413-432. Almodôvar (2010), Almodôvar, Câmara Municipal.

Valenzuela, S. e Detry, C. (2017): "Romanización y Arqueozoología en el limes del Imperio. El caso de Lusitania entre la Edad del Hierro y el Bajo Imperio (s. VIII a.C.-V d.C.)". Archaeofauna 26: 39-51. http://hdl.handle.net/10261/156922

Viegas, C. e Arruda, A. M. (1999): "Cerâmicas islâmicas da Alcáçova de Santarém”. Revista Portuguesa de Arqueologia 2-2: 105-186.

Zbyszweski, G.; Ferreira, O. da V. e Santos, C. (1968): "Acerca do campo fortificado de Chões de Alpompé (Santarém)". O Arqueólogo Português III-2: 49-57. 